\title{
Antibody-Based Sensors: Principles, Problems and Potential for Detection of Pathogens and Associated Toxins
}

\author{
Barry Byrne ${ }^{1,2}$, Edwina Stack ${ }^{2,}$ Niamh Gilmartin ${ }^{2,3}$ and Richard O’Kennedy ${ }^{1,2,3, *}$ \\ 1 Centre for Bioanalytical Sciences (CBAS), Dublin City University, Dublin 9, Ireland; \\ E-Mail: Barry.Byrne@dcu.ie (B.B.) \\ 2 National Centre for Sensor Research (NCSR), Dublin City University, Dublin 9, Ireland; \\ E-Mails: Edwina.Stack3@mail.dcu.ie (E.S.); Niamh.Gilmartin@dcu.ie (N.G.) \\ 3 Biomedical Diagnostics Institute (BDI), Dublin City University, Dublin 9, Ireland \\ * Author to whom correspondence should be addressed; E-Mail: Richard.OKennedy@dcu.ie; \\ Tel.: +353-1-700-5319; Fax: +353-1-700-5412
}

Received: 7 April 2009; in revised form: 26 May 2009 / Accepted: 26 May 2009 /

Published: 5 June 2009

\begin{abstract}
Antibody-based sensors permit the rapid and sensitive analysis of a range of pathogens and associated toxins. A critical assessment of the implementation of such formats is provided, with reference to their principles, problems and potential for 'on-site' analysis. Particular emphasis is placed on the detection of foodborne bacterial pathogens, such as Escherichia coli and Listeria monocytogenes, and additional examples relating to the monitoring of fungal pathogens, viruses, mycotoxins, marine toxins and parasites are also provided.
\end{abstract}

Keywords: pathogen; antibody; biosensor; electrochemical; surface-plasmon resonance; assay development

\section{Introduction}

Pathogenic bacterial, fungal and viral cells are ubiquitous in nature and pose a considerable risk to human and animal health, in addition to severely compromising the quality of agricultural produce (Table 1). Therefore, the monitoring of these microorganisms is of paramount importance for the prevention of nosocomial infections, the maintenance of general public health and for ensuring 
compliance with legislative and quality standards. The rapid detection and identification of a pathogen is essential, in particular where food samples with short shelf-lives are being analysed, or where the urgent administration of a suitable antimicrobial agent is required to treat a potential fatal infection. Virulent pathogens may often be present in low numbers in samples, demonstrating that high sensitivity and specificity are also absolute necessities. Hence, developing suitable detection methods which permit accurate, rapid and sensitive analysis is essential for monitoring the distribution of pathogens and, most importantly, ensuring customer/patient safety.

Table 1. A selection of pathogenic bacterial, fungal and viral strains and their virulence traits.

\begin{tabular}{|c|c|}
\hline Pathogen & Pathogenic trait \\
\hline \multicolumn{2}{|l|}{ Bacterial Pathogens } \\
\hline Bacillus anthracis & Human pathogen; causative agent of anthrax; toxin producer \\
\hline Bacillus subtilis & Putative human pathogen: causative agent of food poisoning \\
\hline Brucella abortus & Human and animal pathogen; causative agent of brucellosis \\
\hline Campylobacter spp. and C. jejuni & Human pathogen; causative agent of campylobacteriosis \\
\hline Clostridium botulinum & Human pathogen; producer of neurotoxins and causative agent of botulism \\
\hline Escherichia coli $\mathrm{O} 157: \mathrm{H} 7$ & $\begin{array}{l}\text { Human pathogen; causative agent of foodborne illness and producer of toxins, such } \\
\text { as verocytoxin or 'shiga-like' toxin }\end{array}$ \\
\hline Francisella tularensis & Animal pathogen; putative biohazard \\
\hline Legionella pneumophila & Human pathogen; causative agent of Legionnaires disease (legionellosis) \\
\hline Listeria monocytogenes & Human pathogen; causative agent of listeriosis \\
\hline Mycobacterium tuberculosis & Human pathogen; causative agent of tuberculosis \\
\hline Neisseria meningitidis & Human pathogen; causative agent of bacterial meningitis \\
\hline Salmonella typhimurium & Human pathogen; causative agent of salmonellosis \\
\hline Staphylococcus aureus & Human pathogen; causative agent of hospital-acquired infection, toxin producer \\
\hline Yersinia enterocolitica & Human pathogen; causative agent of yersiniosis \\
\hline Yersinia pestis & Human pathogen; potential causative agent of the black plague \\
\hline \multicolumn{2}{|l|}{ Fungal pathogens } \\
\hline Candida albicans & Human pathogen; causative agent of vaginal thrush \\
\hline Puccinia striiformis & Plant pathogen; causative agent of stripe rust \\
\hline Phytophthora infestans & Plant pathogen; causative agent of potato blight \\
\hline Trichophyton rubrum & Human pathogen; causative agent of athlete's foot and ringworm \\
\hline \multicolumn{2}{|l|}{ Viral pathogens } \\
\hline African swine fever virus & Animal pathogen; causative agent of African swine fever \\
\hline Bovine diarrhoea virus & Animal pathogen; causative agent of mucosal erosion and bovine diarrhoea \\
\hline Cowpea mosaic virus & Plant pathogen; causes mosaic pattern, vein yellowing and leaf malformation \\
\hline Ebola virus & Human pathogen; causative agent of severe haemorrhagic fever disease \\
\hline Foot and mouth virus & Animal pathogen; causative agent of acute degenerative disease in cattle \\
\hline Hepatitis $\mathrm{C}$ virus & Human pathogen; causative agent of blood-borne infectious disease \\
\hline Human immunodeficiency virus & Human pathogen; causative agent of acquired immunodeficiency syndrome (AIDS) \\
\hline Rift valley fever virus & Animal pathogen; causative agent of Rift valley fever \\
\hline SARS-associated coronavirus & Human and animal pathogen; causative agent of severe acute respiratory syndrome \\
\hline Tobacco mosaic virus & Plant virus; causes mottling and discolouration of leaves \\
\hline West Nile virus & Human and animal virus; causative agent of West Nile fever and encephalitis \\
\hline
\end{tabular}


Figure 1. Strategy for pathogen detection.

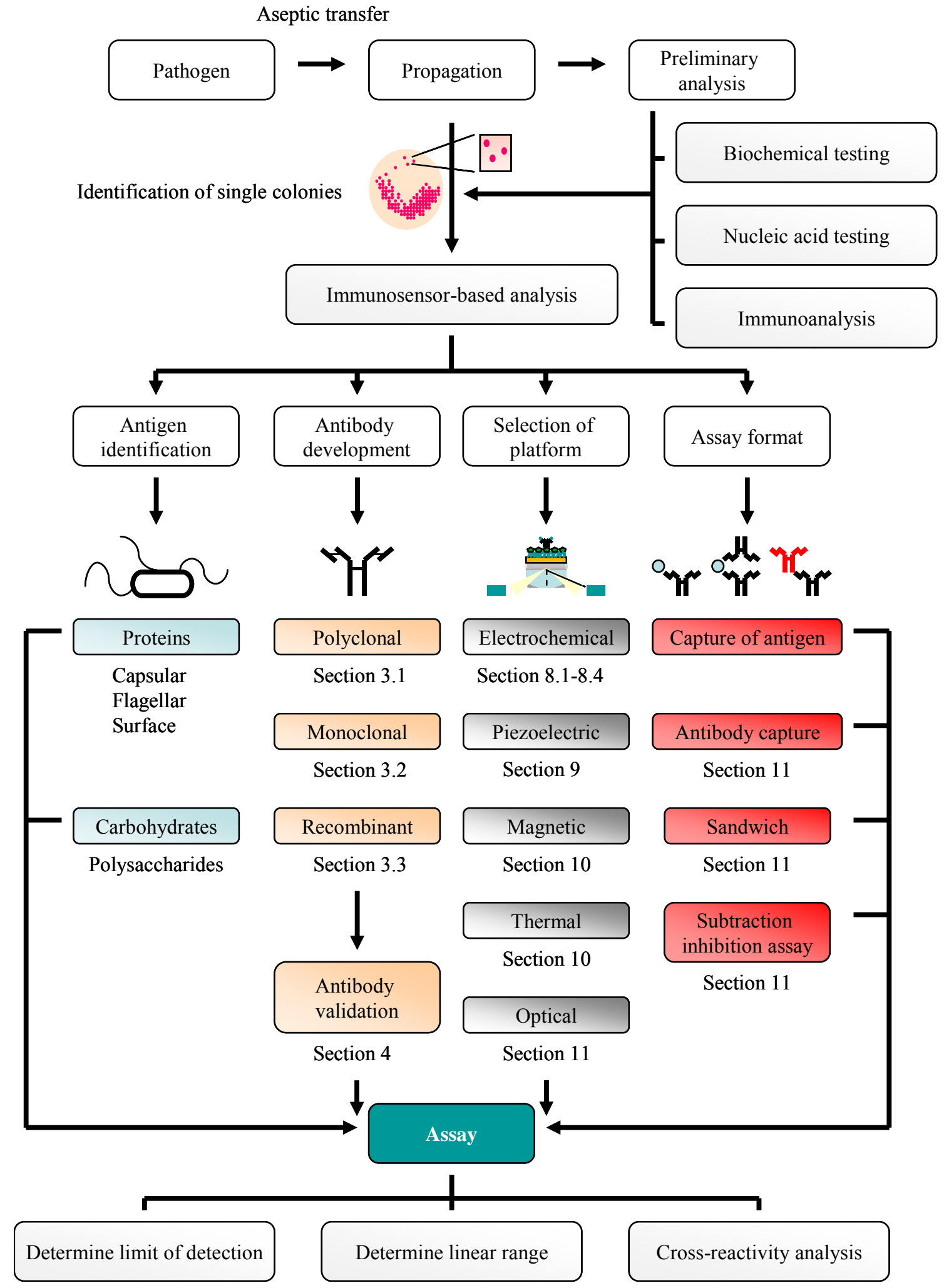

This review provides a comprehensive summary of the principles, problems and potential of using immunosensor-based analytical platforms for pathogen detection. It describes the development of electrochemical, potentiometric, piezoelectric and optical platforms for the monitoring of foodborne bacterial pathogens by incorporating monoclonal, polyclonal or recombinant antibodies in a variety of different assay formats. The overall strategy adapted is shown in Figure 1. The analysis of fungal cells, 
associated toxic secondary metabolites, viral and water-borne pathogens (toxins and parasites) is also outlined. Finally, the advantages of using sensor-based methodologies as an alternative to more traditional methods of pathogen detection, namely bacteriological testing and nucleic acid-based analysis, and alternative sensor-based formats (e.g. biomimetic and plant sensors), will be discussed.

\section{Bacteriological and Nucleic Acid-Based Analysis of Pathogenic Bacteria: A Traditional} Approach

The culturing of pathogenic and non-pathogenic prokaryotic strains involves the aseptic transfer of an innoculum from a source (soil, food etc.) to suitable growth medium which results in amplification of microbial cell numbers, subsequently permitting quantitative determination [1]. This propagation may be performed in the presence of selective markers, such as antibiotics, to suppress the growth of other strains that may also reside in the innoculum. Subsequent transfer to selective or differential media generates colonies that can be distinguished based on their distinctive colony morphologies by ocular inspection (Table 2) and their identification confirmed by rigorous biochemical (glucose utilisation etc.) or nucleic acid-based assays [2].

Table 2. Three commonly encountered bacterial foodborne pathogens with their selective media and epidemiological relevance. Figures obtained for annual estimated cases and infectious doses $\left(^{*}\right)$ are obtained from reference [3] and are representative of figures calculated by the United States Department of Agriculture (USDA) economic research service. Key: CFU - colony-forming units.

\begin{tabular}{|c|c|c|c|c|}
\hline $\begin{array}{l}\text { Strain and } \\
\text { morphology }\end{array}$ & Selective media & $\begin{array}{c}\text { Clinical signs of } \\
\text { infection }\end{array}$ & $\begin{array}{c}\text { Estimated } \\
\text { annual cases } *\end{array}$ & $\begin{array}{c}\text { Infectious doses } \\
(\mathrm{CFU}){ }^{*}\end{array}$ \\
\hline $\begin{array}{l}\text { E. coli } \mathbf{0 1 5 7 : H 7} \\
\text { Gram negative rod }\end{array}$ & $\begin{array}{l}\text { Cefixime rhamnose sorbitol } \\
\text { MacConkey agar [4] } \\
\text { SEL media [5]. }\end{array}$ & $\begin{array}{l}\text { Diarrhoea (bloody) } \\
\text { Renal failure } \\
\text { Haemolytic uraemic } \\
\text { syndrome (rare) }\end{array}$ & 173,107 & $1 \times 10^{1}-1 \times 10^{2}$ \\
\hline $\begin{array}{l}\text { Salmonella spp. } \\
\text { Gram negative rod }\end{array}$ & $\begin{array}{l}\text { Bismuth sulphide agar [4] } \\
\text { SEL media [5] }\end{array}$ & $\begin{array}{l}\text { Cramps } \\
\text { Diarrhoea } \\
\text { Vomiting }\end{array}$ & $1,342,532$ & $1 \times 10^{4}-1 \times 10^{7}$ \\
\hline $\begin{array}{l}\text { L. monocytogenes } \\
\text { Gram negative rod }\end{array}$ & $\begin{array}{l}\text { Listeria enrichment broth }[4,6] \\
\text { Fraser broth }[4] \\
\text { SEL media [5] }\end{array}$ & $\begin{array}{l}\text { Vomiting } \\
\text { Abdominal cramps } \\
\text { Fever }\end{array}$ & 2,493 & $400-1 \times 10^{3}$ \\
\hline
\end{tabular}

Colony count estimation provides an inexpensive and user-friendly protocol for quantitative and qualitative bacterial pathogen detection, and one which is routinely employed in the development of hazard analysis and critical control point (HACCP) systems within the food industry and for the establishment of risk assessments [2,7]. However, a major disadvantage of this approach is the lengthy times required to obtain visible colonies that can be identified. This may take up to 7 days for $L$. monocytogenes cells, cultured using the NF EN ISO 11290-1 protocol [3,8], and over 2 weeks for another important food-related pathogen, Campylobacter fetus [9]. Further complications with using this methodology arise from the ability of some bacterial strains to be viable but non-culturable. This 
phenomenon, and its importance from the perspective of the food industry, has recently been discussed with reference to L. monocytogenes [10] and E. coli O157:H7 [11].

An alternative method for pathogen detection, and one which is often used in conjunction with active culturing to provide sufficient biomass, involves the amplification and subsequent analysis of pathogen-specific nucleic acid by polymerase-chain reaction (PCR) and sequencing (Table 3). The versatility of these methodologies is emphasised by the ability of real-time PCR to provide rapid data analysis of multiplex PCR to facilitate the simultaneous analysis of multiple pathogens and of reversetranscriptase PCR to differentiate between viable and non-viable cells. Furthermore, the presence of bacterial RNAs (mRNA and tmRNA) in food samples can be determined through the use of nucleicacid sequence-based amplification (NASBA) [12,13]. However, the implementation of these methodologies for pathogen detection can be complicated by external factors. For example, strains may originate from complex sample matrices, e.g. food sources that often contain high levels of fats, carbohydrates and other entities which necessitate a sample clean-up stage prior to analysis. Furthermore, as discussed by De Boer and Beumer [7], the amplification of nucleic acid from a pathogenic strain is indicative only of its presence in the sample of interest and cannot be used to monitor toxin production qualitatively or quantitatively. Non-specific DNA amplification may also be observed; the presence of 'naked' DNA in analytical samples may act as a template for the amplification of these superfluous products [14] which complicates fingerprint-based analysis. Therefore, alternative methods of pathogen analysis (e.g. antibody-based) can be more useful.

Table 3. A selection of nucleic acid-based protocols for pathogen detection.

\begin{tabular}{llc}
\hline \multicolumn{1}{c}{ Technique } & \multicolumn{1}{c}{ Pathogen application } & Ref. \\
\hline Real-time PCR & Mycobacterium avium subsp. Paratuberculosis & {$[15]$} \\
& E. coli O157:H7 & {$[16]$} \\
& S. aureus & {$[17]$} \\
& L. monocytogenes & {$[8,18]$} \\
& S. enterica serovar typhimurium & {$[19]$} \\
Multiplex PCR & E. coli O157:H7; Salmonella spp.; Shigella spp. & {$[20]$} \\
& L. monocytogenes and Salmonella spp. & {$[21]$} \\
& Campylobacter spp., Sal monella spp., E. coli, Shigella spp., Vibrio & {$[22]$} \\
& cholerae, Y. enterocolitica & \\
Reverse transcriptase PCR & E. coli O157:H7 & {$[23]$} \\
& E. coli O157:H7, V. cholerae, S. typhi & {$[24]$} \\
Immuno PCR & Streptococcus pyogenes & {$[25]$} \\
& E. coli shiga-toxin 2 & {$[26]$} \\
NASBA & L. monocytogenes & {$[12,13]$} \\
& Campylobacter spp., L. monocytogenes, S. enterica serovar Enteritidis & {$[27]$} \\
\hline
\end{tabular}

\section{Antibodies: Production and Purification}

A schematic representation of a full-length antibody is shown in Figure 2. Polyclonal, monoclonal and recombinant antibodies have frequently been selected for a wide variety of applications, including immunodiagnostics and biomarker detection. Their production involves the exploitation of the immune system of murine, leporine, ovine or avian hosts (Figure 3A). For the production of bacterial pathogen- 
specific antibodies, these hosts may be immunised with cells which may [28] or may not [6] be heattreated (exceptions include naïve antibody phage display libraries which are constructed independently of immunisations; see below). These antigens are typically administered in the presence of a suitable adjuvant, and the immune response generated by the host after a series of immunisations can be determined by screening serial serum dilutions for recognition of the antigen in an enzyme-linked immunosorbent assay (ELISA)-based format.

Figure 2. A schematic representation of an IgG antibody comprising of two heavy (green) and light (blue) chains. Carbohydrate elements are attached via the asparagine 297 amino acid residue. A more in-depth discussion of antibody glycosylation is provided in reference [30]. Key: $\mathrm{V}_{\mathrm{H}}-$ variable heavy, $\mathrm{V}_{\mathrm{L}}-$ variable light, $\mathrm{C}_{\mathrm{H}}-$ constant heavy, $\mathrm{C}_{\mathrm{L}}-$ constant light.

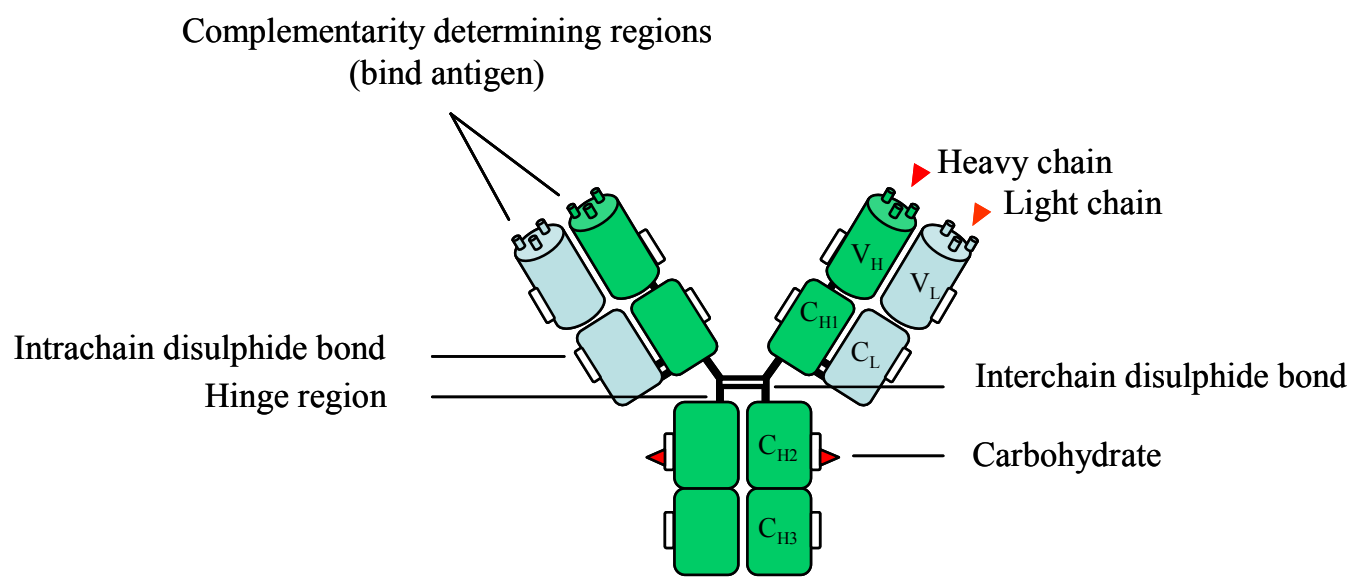

\subsection{Polyclonal Antibodies}

Polyclonal antibodies (pAb) are typically raised in rabbits, goats or sheep [29], and their popularity is illustrated by the fact that they are frequently selected in immunosensor-based assays for pathogen detection. It should be stressed that the inherent nature of pAbs means that a selection of different epitopes may often be recognised on a single cell. In cases where this is undesirable, such as in the case where high specificity is a requirement, monoclonal or recombinant antibodies may be more applicable.

\subsection{Monoclonal Antibodies}

Monoclonal antibodies are generated through the use of hybridoma technology [31,32] and murine hosts are commonly selected for immunisation. The bone marrow, primary lymph nodes and, most commonly, the spleen are selected as a source of antibody-producing B cells which are harvested and fused to immortal myeloma cells. The resulting hybrid cells (referred to as hybridomas) subsequently secrete full-length antibodies that are directed towards a single epitope. Suitable candidates, identified by ELISA-based analysis, are then 'cloned out' to ensure that a single cell, producing antibody specific for an individual epitope, is present and the antibody generated can be used for assay development. 


\subsection{Recombinant Antibodies}

Recombinant antibodies, generated through the use of phage display technology and the biopanning of antibody repertoires (libraries) against a target of interest [33,34], have been selected for the detection of a range of structurally diverse antigens, including proteins [35], haptens [36] and carbohydrate moieties [37]. Three types of library may be used as sources of antibody pools; namely synthetic, naïve and immune. Synthetic libraries are produced by PCR-based randomisation of complementarity-determining regions (CDR) from heavy and/or light chains, and naïve antibody libraries are typically assembled from B-cells extracted from unimmunised human donors. Immune libraries are constructed from RNA isolated from spleenocytes or the bone marrow of a host (avian, murine, leporine etc.) immunised with an antigen that generates the required immune response. The RNA acts as a source of complementary DNA (cDNA) which, in turn, serves as a template for the amplification of variable heavy $\left(\mathrm{V}_{\mathrm{H}}\right)$ and variable light $\left(\mathrm{V}_{\mathrm{L}}\right)$ gene sequences which can be fused through an overlapping-extension splicing PCR reaction and subsequently cloned into a suitable phage or phagemid vector (Figure 3A) [note that in the case of fragment antigen binding (Fab) construction (see below), this process involves the fusion of variable and constant regions]. The introduction of this construct into suppressor strains of E. coli (such as XL1 Blue) by electroporation, in conjunction with the packaging of phage particles via the addition of helper phage (a process referred to as rescuing), allows the encoded antibody structure to be 'presented' on the exterior of a bacteriophage particle, as illustrated in Figure 3B. Two types of antibody fragments may be presented, namely the single-chain variable fragment (scFv) and the Fab, and these are illustrated in Figure 3C and 3D. The production of these fragments is dependent on the vector selected for harbouring the library [38].

Biopanning is used for the selection of binders from an antibody library which may contain between $10^{7}$ and $10^{10}$ different antibody-encoding gene sequences. To achieve this, the antigen is immobilised on solid phase (e.g. on a column or immunotube) or bead-conjugated (in solution phase) and the antibody pool is subjected to recurrent rounds of selection against the antigen with increasing levels of stringency in terms of binding ability. Selected binders are retained and subjected to additional screening to increase their specificity for the target (affinity maturation), which can be monitored by ELISA-based analysis. The production of soluble antibody fragments can be facilitated by infecting phage pools into non-suppressor E. coli strains, such as Top-10F' or HB2151, and inducing with isopropyl- $\beta$-D-1-thiogalactopyranoside (IPTG) in the presence of low concentrations of glucose. These hosts recognise the amber (AUG) codon engineered between the $\mathrm{scFv}$ and gIII gene [39], producing $\mathrm{scFv}$ or Fab fragments independent of the phage coat proteins.

The majority of the examples given in this review involving immunosensor-based pathogen detection incorporate monoclonal or polyclonal antibodies. However, recombinant antibodies are as yet not fully exploited in this field and have several significant advantages over conventional antibodies. The specificity and sensitivity of recombinant antibodies for a particular antigen can be significantly enhanced by the targeting of CDR regions using site-directed mutagenesis or chain shuffling [40,41]. Further advantages include the capacity to incorporate tags (e.g. His or C-myc) for isolation and, subsequently, immobilisation, the ability to fuse various labels (e.g. green fluorescent protein or enzymes) directly to the antibody fragment facilitating and simplifying detection, and the availability of a range of antibody formats (e.g. scFv, Fab, re-engineered IgG, dimers etc.). Avian 
hosts, in particular, have been shown to be useful for the production of high-affinity recombinant antibodies $[35,42,43]$.

Figure 3. An overview of monoclonal, polyclonal and recombinant antibody production [A]. Immunisation-related stages are represented by a red line, with those involving antibody production shown in black. A more in-depth discussion of the generation of recombinant antibodies, inclusive of Fab fragments, can be found in reference [38]. Additional hosts may also be used for antibody production, including camels (camelid), sheep (ovine) and pigs (porcine). A filamentous phage displaying scFv antibody fragments [B] and two recombinant antibody fragments, the scFv [C] and Fab [D], are also illustrated. Key: pIII/pVIII - protein 3/8, $\mathrm{V}_{\mathrm{H}}$ - variable heavy, $\mathrm{V}_{\mathrm{L}}$ - variable light.

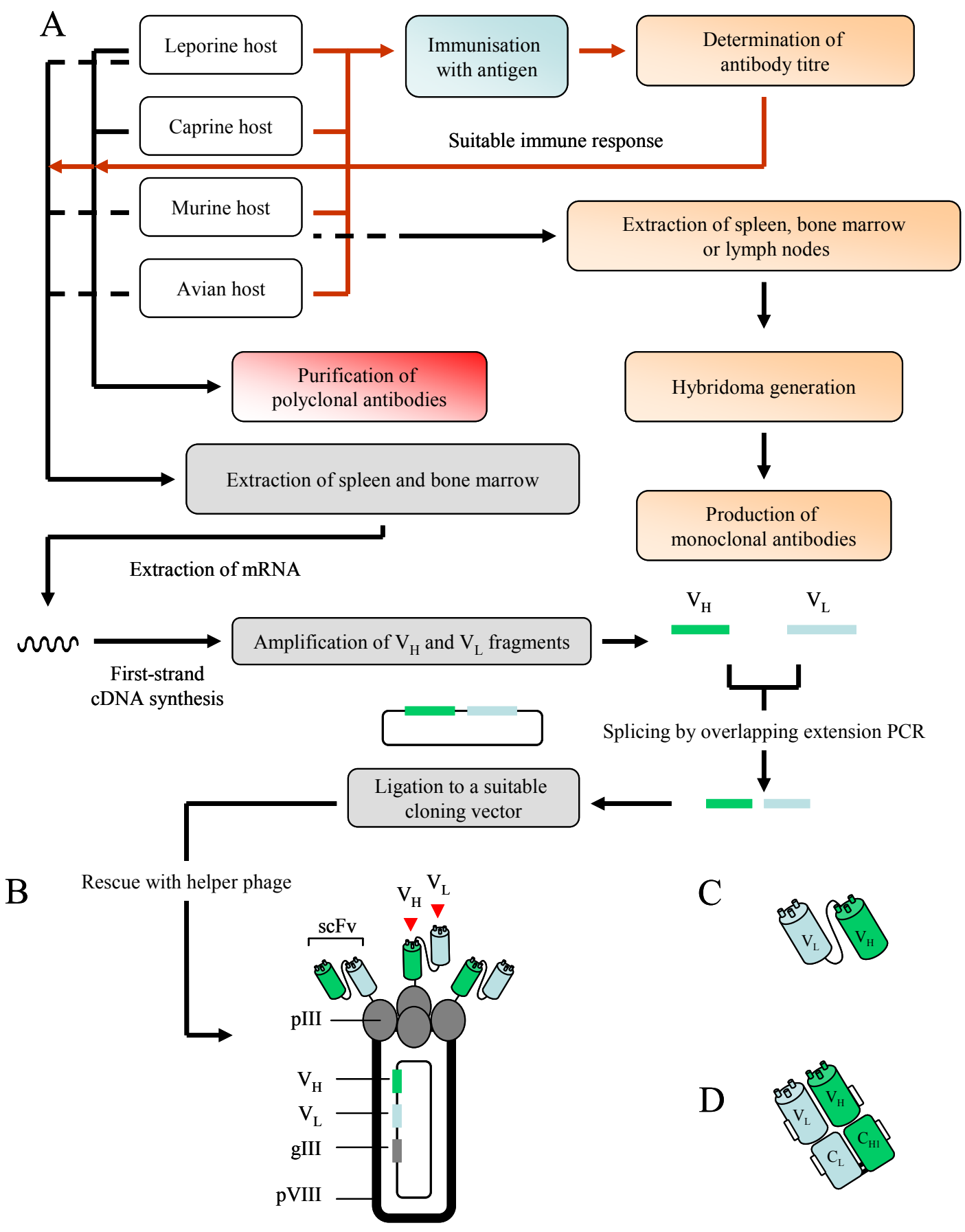




\section{Antibody Selection}

When selecting monoclonal, polyclonal or recombinant antibodies for the detection of pathogens, certain characteristics are of great importance. Firstly, the antibody should be able to detect and quantify very low cell numbers (sensitivity) and this may frequently be an issue for foodborne-related bacterial pathogens (Table 2).

Secondly, it should be able to differentiate specific strains of interest from related microflora which may also reside in the sample (specificity). Hence, the selection of a highly-specific epitope on the pathogen is a key consideration, since many bacterial strains share homologues of surface-presented proteins which can lead to the detection of multiple cell-types by a single antibody. It is therefore recommended that a constitutively-expressed antigen, which is species-specific, is targeted [3]. Where possible, the expression of this target antigen should not be highly dependent on the growth matrix of the pathogen. Finally, the antibody should bind with its cognate target with sufficient strength to permit interrogation (high-affinity). The identification of an antibody candidate that satisfies these requirements can be facilitated through screening by ELISA-based analysis to reduce the number of potential antibodies to a smaller number which can subsequently be screened by sensor-based analysis to identify the candidate with the best affinity for the target epitope. This antibody can then be further selected for incorporation on an immunosensor-based platform.

\section{Use of Antibodies for Antigen Isolation/Enrichment Prior to Analysis}

Antibodies can be successfully used to isolate and collect pathogens from complex matrices where numbers are low and the sample volume is large. Immunomagnetic separation (IMS) involves the coating of a pathogen-specific antibody on a magnetic bead which can be used to facilitate binding, concentration and removal of pathogenic cells from a complex sample media (provided that the antibody has sufficient specificity). Retrieved cells can then be propagated on selective of differential media. The versatility of this technique is further illustrated by the ability to detect pathogen-antibody complexes with beads coated with a cognate secondary antibody, an indirect assay format demonstrated by Torensma and co-workers [44] for the detection of L. monocytogenes cells bound to a murine monoclonal antibody produced from the immunisation with whole bacterial cells. IMS has also been applied for the detection of these cells in cheese [45], S. typhimurium in bovine faecal matter [46] and E. coli $\mathrm{O} 157: \mathrm{H} 7$ in beef carcasses [20,47] and bovine faeces [48].

\section{ELISA and Microarray-Based Pathogen Detection}

ELISA-based analysis can be directly applied for the detection of foodborne pathogens. Brooks and co-workers [9] developed an ELISA-based assay for the detection of C.fetus in bovine preputial washing and vaginal mucous samples. A sandwich assay format was developed by Kerr et al. [49] for the detection of a selection of different E. coli O157:H7 strains from human and animal subjects by using a monoclonal antibody specific for a fimbrial antigen. The limit of detection was similar to that found by Brooks et al. $\left(1 \times 10^{5} \mathrm{CFU} / \mathrm{mL}\right)$. ELISA-based assays have also been described for the detection of L. monocytogenes [50,51] and Salmonella enterica spp. [52]. A major drawback of these 
assay formats is that analysis times are often lengthy. Typical ELISA assays are comprised of a number of steps; namely blocking, washing, incubation of primary and secondary antibodies and substrate development. These can take several hours to complete and, understandably, this may be problematic in instances where rapid detection is a requisite.

Protein microarrays are excellent candidates for high-throughput analysis of biomolecular interactions in miniaturised assays formats [53]. The implementation of antibodies on such platforms for pathogen detection offers a flexible approach for the screening of high number of bacterial isolates from numerous sample matrices. Array formats typically consist of a panel of pathogen-specific antibodies spotted onto individual positions on a microarray slide by dedicated robotic handling (printing), with subsequent pathogen detection commonly employing sandwich ELISA assay formats. Gehring and colleagues [54] printed a biotinylated antibody (caprine-derived) for E. coli $\mathrm{O} 157: \mathrm{H} 7$ on a streptavidin-coated microarray slide. Captured cells were further probed with a fluorescein-labelled secondary antibody and microarray spots were visualised through the use of fluorescent microscopy. This sandwich assay format had a linear range of detection of $3 \times 10^{6}-9 \times 10^{7}$ cells $/ \mathrm{mL}$. Cai et al. [55] developed an antibody microarray capable of the parallel analysis of somatic $(\mathrm{O})$ and flagellar $(\mathrm{H})$ antigens on 117 Salmonella strains from twenty commonly encountered serovars, including typhimurium, heidelberg and enteritidis. Thirty five polyclonal antibodies from rabbit antiserum were spotted in pairs on commercially obtained microarray slides and used for the capture of Eosin Yfluorescently labelled cells. Over $73 \%$ of the strains selected for analysis were positively identified, with an additional 30 strains partially serotyped. The ability of this assay format to selectively differentiate between related and unrelated Salmonella strains was demonstrated by the analysis of an additional 73 strains selected from a panel of almost forty non-target serovars. Anjum et al. [56] also targeted O-antigen groups of $17 \mathrm{E}$. coli strains with rabbit polyclonal antisera. The ability of these microarray formats to screen numerous bacterial pathogens in parallel was further illustrated by the printing of individual antibodies in a 96-well polystyrene plate by an 'in-house' robotic printing system. This cost-effective array format, devised by Gehring and colleagues, was selected for the simultaneous detection of E. coli $\left(1 \times 10^{6}\right.$ cells $\left./ \mathrm{mL}\right)$ and Salmonella typhimurium $\left(1 \times 10^{7}\right.$ cells $\left./ \mathrm{mL}\right)$ in buffer and ground beef extract [57] and further illustrates the versatility of such antibody-based formats. Finally, antibody-based microarray platforms have been selected for the sensitive and parallel detection of structurally diverse pathogens. These include bacterial strains that pose a potential bioterrorism risk (e.g. Burkholderia mallei, F. tularensis and Y. pestis) and viral particles (e.g. West Nile virus) [58], foodborne pathogens (Campylobacter jejuni) and mycotoxins [59] and, finally, sporeforming bacterial cells (B. globigii) and toxins [60]. The latter assays [59,60] implement the Naval Research Laboratory (NRL) array biosensor. This elegant platform can simultaneously detect pathogenic bacterial cells and toxins, and can perform sandwich (as is the case with many of these examples) and competition immunoassays in parallel with an assay time of approximately 15 minutes [59]. Toxin and virus-related pathogen detection is discussed in sections 13 and 14 with reference to immunosensor-based analysis. 


\section{Biosensors}

Biosensors are analytical devices which combine a biological recognition ligand with physical or chemical signaling devices (transducers). The recorded biomolecular interactions are transformed into digital signals which are interpreted by a computer-aided readout, thereby providing the user with a representation of the interaction that occurs between the bound (ligand) and free (analyte) entities (Figure 4). Many different sensor formats have been utilised for pathogen analysis using antibodies; namely electrochemical, mass-based, magnetic and optical. The sensitivities of these assays are dependent on the properties of the transducer and the quality of the antibody. An overview of each sensor type and an explanation of how antibodies can be incorporated for pathogen detection follows.

Figure 4. A simple representation of a biosensor. Here, a full-length antibody is captured on protein A immobilised on a carboxymethylated dextran-coated sensor surface and is used for the capture of an analyte. This interaction produces a specific physicochemical change, such as a change in mass, temperature or electrical potential. This is then converted (via a transducer) to a signal which the user can interpret.

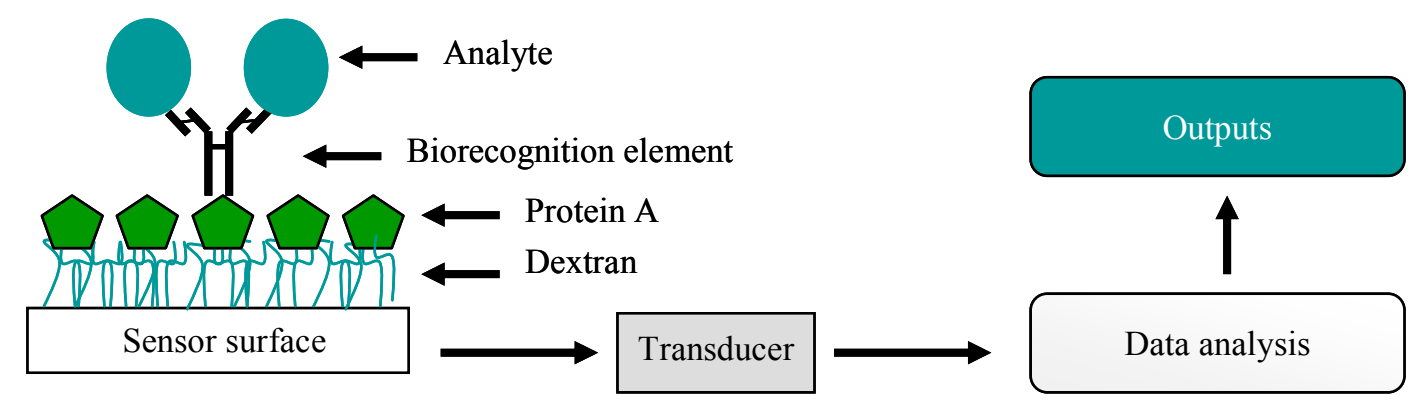

\section{Electrochemical Immunosensors}

The principle behind these assay formats is the coupling of a specific antibody with an electrode transducer which functions to convert a binding event into an electrical signal. In general, electrochemical biosensors can be based on four transducer types; namely amperometric, impedimetric, potentiometric and conductimetric.

\subsection{Amperometric Platforms}

Many amperometric biosensors utilise an enzyme-based system that generates an electroactive product which can be oxidised or reduced at a working electrode (carbon, gold etc.). The resultant current can then be detected. This format has several advantages, including the capacity to fabricate disposable and customised screen-printed electrochemical electrodes (screen-printed carbon electrodes) by depositing inks (carbon, silver etc.) in a pre-determined arrangement and thickness [61]. These systems are economical, robust and sensitive and can be used in conjunction with mediators such as ferrocenedicarboxylic acid (FEDC) or iodine to improve selectivity [3]. Furthermore, there is major potential to miniaturise these systems. This leads to smaller sample volume requirements. 
Gehring et al. [62] developed an amperometric assay for the detection of S. typhimurium cells which were captured with magnetic bead-conjugated antibodies and detected with an alkalinephosphatase (AP)-labelled goat anti-Salmonella antibody. After deposition of the beads on graphite ink electrodes, the AP-catalysed production of electroactive para-aminophenol (PaP) from its substrate, para-aminophenyl phosphate (pAPP), was monitored electrochemically and the generated signal was directly proportional to the number of captured bacterial cells. This assay had a sensitivity of $8 \times 10^{3}$ cells/mL. Ivnitski and co-workers [63] also applied this methodology for the detection of Campylobacter. Here, anti-Campylobacter antibodies were embedded in a bilayer lipid membrane and, upon binding with free cells, a conformational change was introduced which allowed the transport of ions through the membrane. The resultant current was detected amperometrically via a stainless steel electrode. This rapid (10 minutes) assay allowed the researchers to verify that $10^{10}$ ions could pass through the channel per second. This value was correlated with a theoretical value of one bacterial cell per sample. Lin and co-workers [64] recently immobilised a monoclonal antibody on screen-printed carbon electrodes (SPCE) for the capture of pure cultures of E. coli O157:H7, and implemented a horseradish peroxidase (HRP)-labelled polyclonal antibody for detection in an indirect sandwich assay format. It was noted that the attachment of gold nanoparticles and the use of FEDC, as a mediator, resulted in a noticeable amplification of the response current generated. This enabled the detection of approximately $5 \times 10^{3} \mathrm{CFU} / \mathrm{mL}$ in 1 hour. The assay had excellent selectivity and specificity, with minimal cross-reactivity observed when groups of other food pathogens were tested in parallel $(L$. monocytogenes, Salmonella choleraesuis and Vibrio paraheamolyticus ), thus illustrating the importance of having a selective biorecognition element. Crowley and colleagues [65] also selected a SPCE-based platform for L. monocytogenes detection. A direct sandwich assay format, consisting of a leporine polyclonal capture antibody and an AP-labelled detection antibody, could detect $9 \times 10^{2}$ cells $/ \mathrm{mL}$. Comparable sensitivity was observed when polyclonal goat $\left(1 \times 10^{3}\right.$ cells $\left./ \mathrm{mL}\right)$ andrabbit $\left(9 \times 10^{2}\right.$ cells $\left./ \mathrm{mL}\right)$ antibodies were used for capturing cells in an indirect sandwich assay format. The direct immobilisation of $L$. monocytogenes cells on the SPCE provided a low response.

\subsection{Impedimetric Platforms}

Impedimetric biosensors are often based on the fact that the metabolic redox reactions of microorganisms are detectable and quantifiable when performed in the presence of a suitable mediator [66]. Hence, viable microbial biomass can be determined by monitoring microbial 'metabolism' which, in turn, increases conductance and capacitance and results in a decrease in impedance. Similarly to amperometric biosensors, several elegant antibody-based impedimetric assays have been used for pathogen detection. Radke and Alocilja [67] developed a high-density microelectrode array for the sensitive detection of E. coli O157:H7 $\left(1 \times 10^{4}-1 \times 10^{7} \mathrm{CFU} / \mathrm{mL}\right)$ using a goat anti-IgG polyclonal antibody for capture. Tully and colleagues recently implemented a biotinylated leporine polyclonal antibody for the detection of internalin B ( $\mathrm{InB}$ ), a L. monocytogenes cell-surface protein. When captured on avidin-coated planar carbon electrodes modified with polyaniline, a conductive polymer, the limit of detection for InB was found to be $4.1 \mathrm{pg} / \mathrm{mL}$ [68]. The versatility of using this approach for the detection of this bacterium was also illustrated by Wang et al. [69] who adopted a different protocol by immobilising a monoclonal antibody on a titanium- 
dioxide nanowire to detect $1 \times 10^{2} \mathrm{CFU} / \mathrm{mL}$. Finally, Su and Li [70] demonstrated how a quartz crystal microbalance (QCM) system using impedance could detect S. typhimurium in chicken meat. The implementation of magnetic beads resulted in a significant improvement in assay sensitivity, with a limit of detection of $1 \times 10^{2}$ cells $/ \mathrm{mL}$. Minimal cross-reactivity was observed with E. coli.

\subsection{Potentiometric Platforms}

In potentiometric biosensors the conversion of a biorecognition process into a change in potential signal is detected by a reference electrode. Potentiometric biosensor formats typically consist of a perm-selective outer layer and a bioactive element, such as urease, may be introduced to enhance the performance of the assay [3]. A methodology that combines potentiometric and optical detection, namely the light-addressable potentiometric sensor (LAPS), was shown to be applicable for pathogen detection. Gehring et al. [71] implemented this technology in conjunction with an immune-ligand assay (ILA) for the detection of E. coli O157:H7. The assay format devised involved the enumeration of cells by biotinylated polyclonal capture and fluorescein-labelled detection antibodies which were raised in caprine hosts through the administration of heat-killed cells. This 'sandwich' complex (in the presence of an additional urease-labelled anti-fluorescein antibody) was subsequently captured on a streptavidin-bovine serum albumin (BSA)-coated nitrocellulose membrane. Urease enzymatic activity was monitored by the hydrolysis of urea to carbon dioxide and ammonia. The authors were able to detect approximately $7.1 \times 10^{2}$ cells $/ \mathrm{mL}$ and $2.5 \times 10^{4}$ cells $/ \mathrm{mL}$ of heat-killed and live cells of $E$. coli, respectively, in buffered solutions. Dill and co-workers [72] utilised a silicon chip-based LAPS assay to detect low levels (119 CFU) of S. typhimurium. Here, biotinylated and fluorescein-labelled antiSalmonella antibodies were selected as biorecognition elements. This assay format was subsequently applied for the monitoring of chicken carcass washings spiked with Salmonella cells, and demonstrated a high recovery rate for cells $(90 \%)$.

\subsection{Conductimetric Platforms}

The final electrochemical immunosensor format that will be discussed, with reference to the detection of E. coli and Salmonella spp., is based on conductimetric detection [73]. Here, a biological signal is converted to an electrical signal via a conductive polymer, such as polyacetylene, polypyrrole or polyaniline. Muhammad-Tahir and Alocilja [74] developed a conductimetric biosensor incorporating a polyclonal antibody-based sandwich assay format in which the detection antibody was labelled with polyaniline. This sensor could detect approximately $79 \mathrm{CFU} / \mathrm{mL}$ and $83 \mathrm{CFU} / \mathrm{mL}$ of $E$. coli O157:H7 and Salmonella spp., respectively. This approach was also used for the detection of $E$. coli cells in a selection of different sample matrices, including lettuce and strawberries [75]. The sensitivity recorded was $81 \mathrm{CFU} / \mathrm{mL}$. Furthermore, the assay was rapid (6 minutes) and could be generated in a disposable format.

Hnaiein and co-workers [76] developed a novel conductimetric immunosensor for E. coli. A biotinylated polyclonal antibody was captured on streptavidin-coated magnetite nanoparticles. These were subsequently bound on a conductimetric electrode through the use of glutaraldehyde coupling. Conductimetric measurements were facilitated through the application of an alternating-current (ac) 
voltage. The incorporation of nanoparticles facilitated an increase in conductivity, enabling $0.5 \mathrm{CFU} / \mathrm{mL}$ to be detected. A small amount of background was observed when S. epidermis cells were assayed in parallel. This was attributed to the use of a polyclonal capture antibody and reinforces the view that in some assay formats, monoclonal or recombinant antibodies may be more suitable.

\section{Mass-Based Immunosensors}

Piezoelectric biosensors operate on the principle that a change in mass, resulting from the biomolecular interaction between two entities, such as an antibody and its respective antigenic determinant, can be determined [77]. For example, in a quartz crystal, mass changes result in alterations in resonance frequency. Piezoelectric immunosensors are affordable and disposable options for pathogen detection, and the implementation of QCM for the direct detection of analytes, such as bacterial cells, alleviates the need for labelled secondary antibodies [78]. Babacan and co-workers [79] demonstrated that the use of protein A for the capture of a polyclonal antibody to S. typhimurium enhanced reproducibility and surface stability when compared to polyethyleneimine-glutaraldehyde (PEI-GA) coupling. The resultant assay format permitted the detection of $1.6 \times 10^{9} \mathrm{CFU} / \mathrm{mL}$.

Fung and Wong [80] described how the use of ethyl-N'-(3`dimethylaminopropyl)-carbodiimide hydrochloride (EDC) and N-hydroxysuccinimide (NHS) coupling, a methodology routinely selected for the immobilisation of ligands on optical sensor platforms, allowed the capture of a monoclonal antibody for $S$. paratyphi A. The use of this surface immobilisation chemistry was shown to provide good stability and sensitivity, with a limit of detection of $1.7 \times 10^{2}$ cells $/ \mathrm{mL}$. With respect to both of these formats and previously mentioned assays involving protein A immobilisation [70], the selection of a proper strategy for correctly orientating antibodies is conducive to enhanced sensitivity and selectivity. Kim and co-workers [81] used a QCM platform based on impedance measurement for the detection of S. typhimurium (the limit of detection was approximately $1 \times 10^{3} \mathrm{CFU} / \mathrm{mL}$ ). Su and $\mathrm{Li}$ [78] developed a piezoelectric sensor for detecting between $1 \times 10^{3}$ to $1 \times 10^{8} \mathrm{CFU} / \mathrm{mL}$ of E. coli O157:H7 through the implementation of antibodies on a QCM via a 16-mercaptohexanedecanoic acid (MDHA) monolayer. Pohanka et al. [82] used a polyclonal antibody linked to the piezoelectric crystal surface using glutaraldehyde to detect $E$. coli. The resulting assay was rapid, permitting analysis in ten minutes (inclusive of a regeneration step for re-analysis), and greater than ten assays could be performed without the need for re-calibration. This 'label-free' assay had a limit of detection of $1 \times 10^{6} \mathrm{CFU} / \mathrm{mL}$.

\section{Thermometric and Magnetic Immunosensors}

In therometric biosensors thermistors are frequently selected as temperature transducers [83]. Magnetic biosensors, in contrast, implement magnetic beads coated with a suitable ligand that can be detected within a magnetic field. From the perspective of bacterial pathogen detection, the latter platforms have been explored to a greater degree than their thermometric counterparts. Magnetic systems offer distinct advantages. For example, when a sample selected for analysis does not contain any contaminating materials with magnetic properties, background signals (non-specific) are minimised. Ruan and colleagues [84] immobilised anti-E. coli antibodies on a magnetoelastic 
cantilever through the construction of a self-assembled monolayer (SAM). The principle of this assay was the conversion of a substrate, 5-bromo-4-chloro-3-indolyl phosphate (BCIP), to an oxidised and insoluble blue precipitate via an AP-catalysed reaction (secondary antibody). This product accumulated on the sensor surface, and the resulting changes in resonance frequency were recorded, facilitating the detection of $1 \times 10^{2}$ cells $/ \mathrm{mL}$ of E. coli O157:H7. Mujika et al. [85] recently developed a magnetoresistive sensor for the detection of E. coli. It consisted of a sandwich assay whereby the bacterial cells were captured with a polyclonal antibody and detected using leporine polyclonal antibodies coated on superparamagnetic beads. The application of an external magnetic field was used for monitoring. This assay had a sensitivity of $1 \times 10^{5} \mathrm{CFU} / \mathrm{mL}$ of E. coli O157:H7. Furthermore, minimal cross-reactivity was seen when $S$. choleraesuis was tested on this format. With reference to immobilisation strategies, when comparative analysis was performed between three different materials, silicon nitride was found to be more suitable than silicon dioxide $\left(\mathrm{SiO}_{2}\right)$ and $\mathrm{SU}-8$ for antibody capture. Finally, this sensor format was hand-held, and these miniaturised formats demonstrate one approach for 'on-site' pathogen detection.

In conclusion, electrochemical, piezoelectric and magnetic immunosensors can all be applied to foodborne pathogen detection. Optical platforms also offer a powerful and 'label-free' methodology that permits 'real-time' pathogen detection, and these are discussed in section 11.

\section{Optical Immunosensors}

Surface-plasmon resonance (SPR) is a phenomenon that results from the illumination of a metallic surface, such as gold, by visible or near-infrared radiation from a monochromatic light source via a hemispherical prism which exits to a detector (photodiode array) at an angle related to the refractive index (RI). The resultant oscillation of free electrons generates surface plasmons (electromagnetic waves) which resonate and absorb light. The specific wavelength/angle at which this occurs is a function of the RI in the proximity of the gold surface and relates to the mass on the chip surface. A change in mass, effected by the immobilisation of a ligand and, subsequently, further interactions which take place when analytes are passed over the modified sensor surface, causes a shift in the resonance to a longer wavelength and, hence, introduces a refractive index change (Figure 5).

A large selection of commercially available optical biosensors can be directly applied for pathogen detection. Wei et al. [88] used the SPREETA ${ }^{\mathrm{TM}}$ SPR system (Texas Instruments) for the detection of Campylobacter jejuni. Here, biotinylated leporine polyclonal antibodies were immobilised directly on the sensor surface and the assay had a sensitivity of $1 \times 10^{3} \mathrm{CFU} / \mathrm{mL}$. Barlen and co-workers [89] selected the Plasmonic SPR device (Plasmonic Biosensoren) for the detection of Salmonella typhimurium $\left(2.5 \times 10^{5} \mathrm{CFU} / \mathrm{mL}\right)$ and S. enteritidis $\left(2.5 \times 10^{8} \mathrm{CFU} / \mathrm{mL}\right)$. Mazumdar and colleagues also selected the same biosensor system for the detection of $S$. typhimurium $\left(1.25 \times 10^{5}\right.$ cells $\left./ \mathrm{mL}\right)$ in milk by implementing leporine polyclonal capture and detection antibodies [90]. A range of other optical sensor platforms, including the ProteOn XPR36 (Bio-Rad) and SensíQ (Nomadics) and Biacore $^{\mathrm{TM}}$ (discussed below) also have the potential to be applied for pathogen monitoring. Oh et al. [91] devised a SPR-based protein chip assay format with immobilised monoclonal antibodies against S. typhimurium, E. coli O157:H7, Yersinia enterocolitica and Legionella pneumophila . $1 \times 10^{5} \mathrm{CFU} / \mathrm{mL}$ of each pathogen could be specifically detected with their respective antibody. 
Figure 5. Representation of the SPR phenomenon, showing the Kretschmann prism arrangement originally proposed in references [86] and [87]. For illustrative purposes, a protein-A (green hexagon)-captured $\mathrm{IgG}$ antibody is shown on a carboxymethylated dextran (CM5) sensor surface. The mass change introduced by the binding of an analyte of interest (blue circle) is shown as a change in refractive index (A to B) which can be determined through the use of dedicated software.

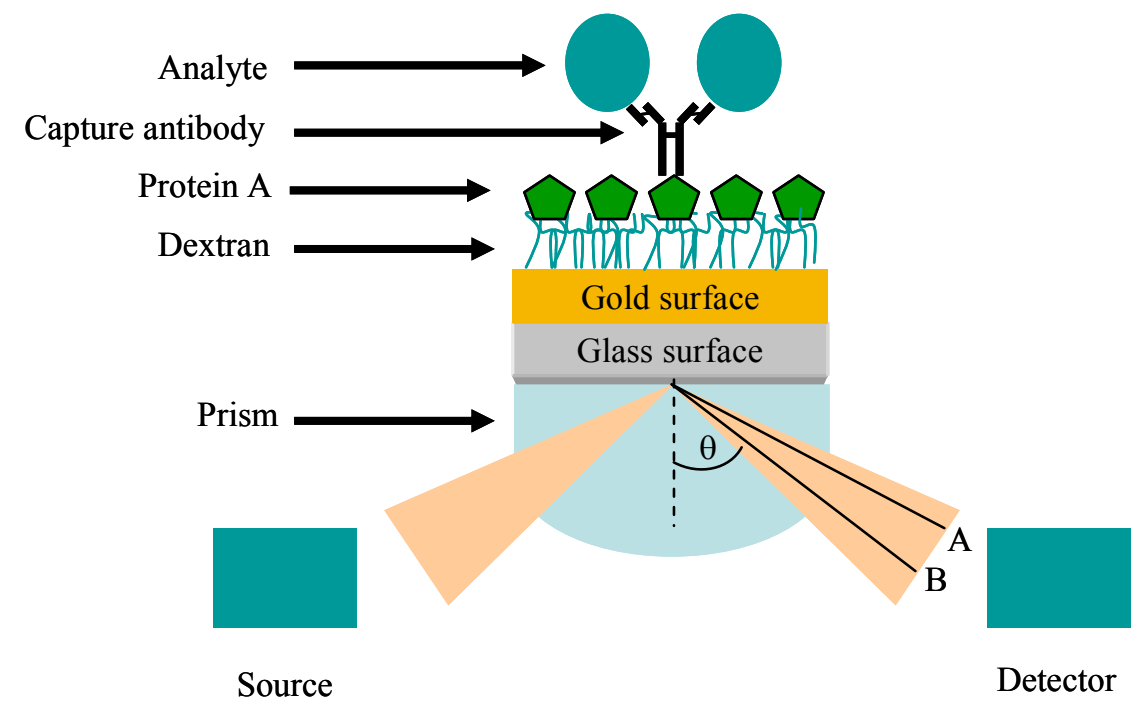

Koubová et al. [92] were able to detect $1 \times 10^{6} \mathrm{CFU} / \mathrm{mL}$ of L. monocytogenes and S. enteritidis on an 'in-house' SPR system, while Taylor et al. [93] devised an eight-channel SPR sensor for permitting the detection of E. coli O157:H7 $\left(1.4 \times 10^{4} \mathrm{CFU} / \mathrm{mL}\right)$, L. monocytogenes $\left(3.5 \times 10^{3} \mathrm{CFU} / \mathrm{mL}\right), C$. jejuni $\left(1.1 \times 10^{5} \mathrm{CFU} / \mathrm{mL}\right)$ and S. choleraesuis $\left(4.4 \times 10^{4} \mathrm{CFU} / \mathrm{mL}\right)$ in buffer (PBS). Rijal and colleagues [94] applied a novel fibre-optic biosensor for the detection of E. coli O157:H7 by immobilising a monoclonal antibody on a silanised (3-aminopropyl-triethoxysilane, APTES) silica fibre-tapered surface using EDC/sulpho-NHS coupling. Changes in light transmission (470 nm) were introduced by pathogen binding, and the assay had a sensitivity of 70 cells $/ \mathrm{mL}$. Alternative fibre opticbased platforms that use fluorescent detection include the Analyte 2,000 [95] and the RAPTOR biosensor. The latter is a portable device that utilises a sandwich ELISA format for detecting pathogens. Typically, a biotinylated capture antibody is immobilised on an avidin-coated fibre-optic waveguide. Four such channels are housed within a plastic disposable 'coupon', thereby permitting parallel analysis to be performed with four different analytes. Detection antibodies are labelled with a fluorophore, typically cyanine 5 (Cy5) [96] or Alexa fluor 647 (AF647) [97]. Fluorescently-tagged molecules that are located within $100-1,000 \mathrm{~nm}$ of the waveguide surface are excited by a diode laser $(635 \mathrm{~nm})$, and a percentage of the emitted fluorescence is detected by an optical probe and quantitated by a photodiode detector that collects emitted light at wavelengths of over $650 \mathrm{~nm}$ [96]. The RAPTOR biosensor has been used for detecting foodborne pathogens, including S. typhimurium in spent water samples of spiked alfalfa seeds [98], L. monocytogenes in frankfurter meat [99] and Enterococcus faecalis from recreational water samples [100]. Pathogens can also be recovered and propagated by incubating waveguides containing bound bacterial cells in selective media post-analysis [98]. 
These examples demonstrate the use of commercial and 'custom-built' SPR systems. A more detailed discussion of Biacore-based analytical approaches will now be provided, together with the problems encountered with these assay formats and methods for overcoming them.

The versatility of Biacore-based analytical platforms is demonstrated by the ability of the researcher to perform capture, sandwich or subtractive-inhibition assays, as shown in Figure 6. Hearty and colleagues [6] produced a murine monoclonal antibody which was shown to be specific for the surface-located L. monocytogenes internalin A (InA) protein in native and recombinantly-expressed forms. When this antibody was immobilised on a CM5 surface through EDC/NHS coupling, a limit of detection of $1 \times 10^{7} \mathrm{CFU} / \mathrm{mL}$ was observed when L. monocytogenes cells were tested. Cross-reactivity studies clearly demonstrated the specificity of this monoclonal antibody, with minimal binding to $E$. coli, B. cereus and Listeria innocua (the latter selected due to the non-expression of the InA protein) observed. This further illustrates the importance of this antibody as a species-specific reagent.

Figure 6. SPR-based assays for pathogen detection. (A) Specific antibody is immobilised and is used to capture the pathogen leading to a signal. (B) Pathogen or pathogen-related antigen is captured. Specificity is conferred by the binding of a second antibody. (C) Specific antibody reacts with the pathogen or pathogen-related antigen. Non-bound (free) antibody is isolated and detected when bound to an immobilised antibody (normally an anti-species antibody) on the chip. In this case, the signal generated is inversely proportional to the pathogen concentration.

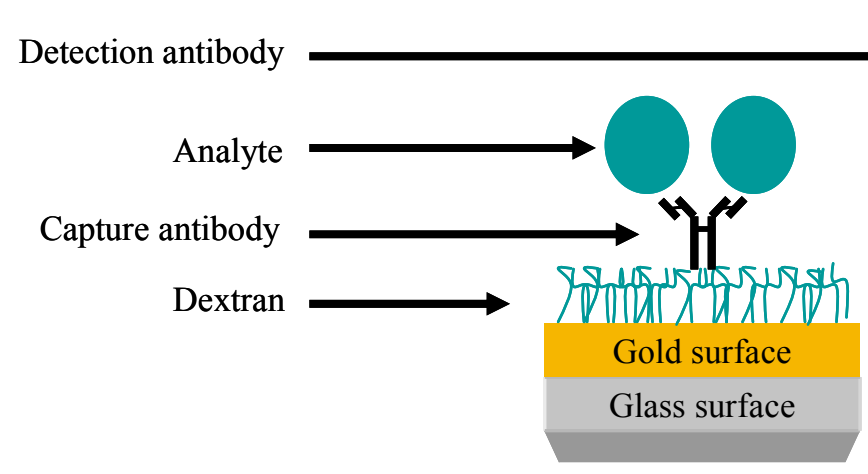

(A) Capture assay

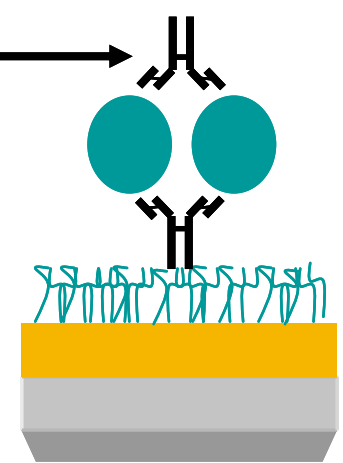

(B) Sandwich assay
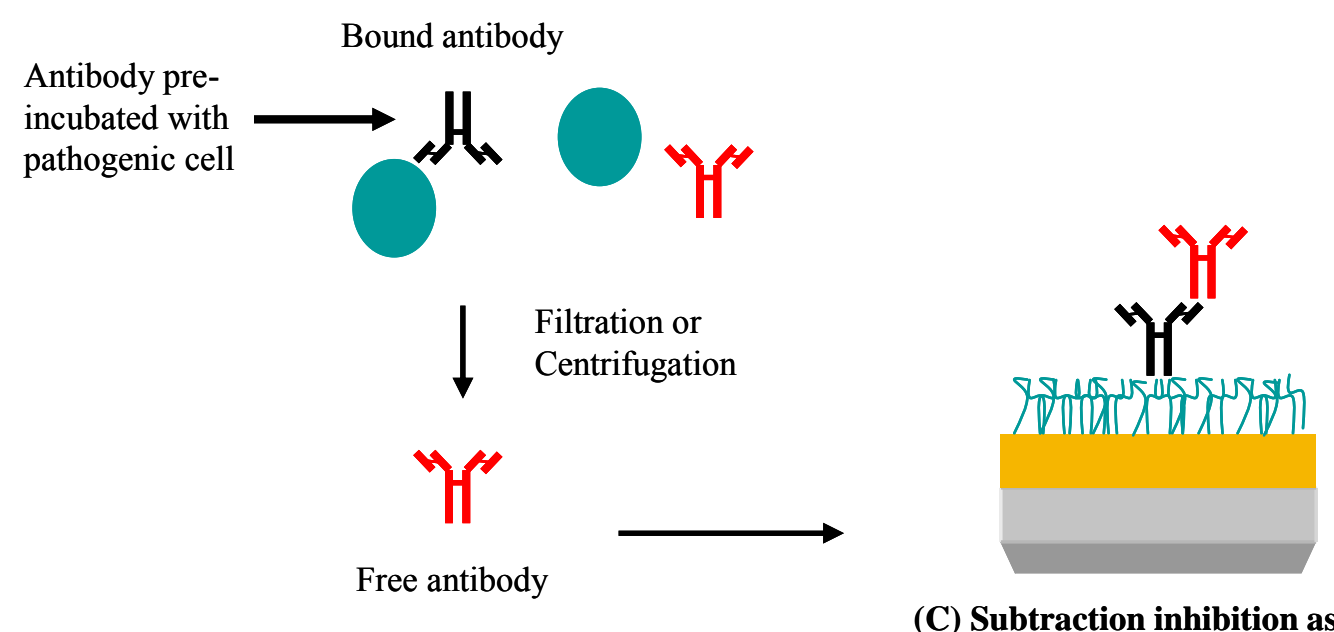

(C) Subtraction inhibition assay 
Sandwich assay formats are routinely selected for increasing sensitivity in ELISA-based analytical platforms. This format was adapted for SPR-based analysis of E. coli O157:H7 and Salmonella by Fratamico and colleagues [101]. They demonstrated that the sensitivity of a capture assay for E. coli O157:H7 cells $\left(5 \times 10^{9} \mathrm{CFU} / \mathrm{mL}\right)$ could be enhanced significantly by the subsequent addition of a caprine polyclonal antibody, which enabled the detection of between 5 and $7 \times 10^{7} \mathrm{CFU} / \mathrm{mL}$.

Another interesting observation deduced from this experimental work related to the immobilisation strategy. The initial experimental format implemented a capture assay format $\left(5 \times 10^{9} \mathrm{CFU} / \mathrm{mL}\right)$. No apparent increase in sensitivity was observed when protein A was used to immobilise the mAb. The ability of a sandwich assay format to enhance sensitivity was also described by Bokken et al. [102] for the detection of Salmonella groups B, D and E. The original capture format permitted the detection of $1 \times 10^{7} \mathrm{CFU} / \mathrm{mL}$. This sandwich format used a monoclonal capture and polyclonal detection antibody, the former immobilised through standard EDC/NHS coupling. This assay format reduced the limit of detection to $1.7 \times 10^{5} \mathrm{CFU} / \mathrm{mL}$. While these assays clearly illustrate the potential that sandwich formats have for increasing assay sensitivity, it should also be mentioned that this is not always successful, as shown by the inability of two anti-L. monocytogenes polyclonal antibodies to enhance the signal in an assay format where cells were originally captured by a mouse monoclonal antibody [6]. There are also additional concerns with using this sandwich format on Biacore-based platforms due to the large size of the bacterial cells which exceeds the penetration depth of an evanescent wave (see section 15).

The subtraction inhibition assay (SIA) is an extremely useful method for pathogen detection in SPR-based immunoassays, and can be selected in instances where the user does not want to expose the system to pathogenic cells or to matrices which may have high viscosities. The principle of this assay format involves pre-incubating an antibody with a target pathogen and separating free from bound antibody. The quantity of free antibody is inversely proportional to the concentration of pathogen. Haines and Patel [103] implemented this assay for the quantification of Salmonella. A polyclonal antibody (specific for cell-wall epitopes) was incubated with freshly-prepared cells and subsequently passed through a syringe filter $(0.22 \mu \mathrm{m})$, enabling unbound antibody to be separated from antibodypathogen complexes. Free antibody was then captured on an anti-Fab-coated CM5 Biacore chip. This novel assay format permitted five different strains to be detected at similar sensitivities $\left(1 \times 10^{4} \mathrm{CFU} / \mathrm{mL}\right)$, and allowed comparative analysis with an additional ten unrelated strains at high concentrations $\left(1 \times 10^{8} \mathrm{CFU} / \mathrm{mL}\right)$ to be performed. No response of any statistical relevance was observed, illustrating the versatility of the SIA assay format to be used for selective analysis. Leonard et al. [28] developed a SIA assay for L. monocytogenes but adopted a different approach. A polyclonal antibody, produced through the immunisation of a rabbit with heat-treated cells, was purified by protein $\mathrm{G}$ affinity chromatography and added to differing concentrations of heat-killed cells in phosphate buffered saline solution (PBS) and incubated at $37^{\circ} \mathrm{C}$ for 20 minutes. A centrifugation step was used as an alternative to filtration for the separation of free polyclonal antibody, and subsequent analysis was performed on a goat anti-rabbit polyclonal antibody immobilised on a CM5 surface. The efficacy of this assay format was illustrated by the low limit of detection $\left(1 \times 10^{5}\right.$ cells $\left./ \mathrm{mL}\right)$, and by the short assay time required to obtain data (30 minutes; excluding preparation of the sensor surface). 


\section{Immunosensor-Based Assays for the Detection of Other Bacterial Pathogens}

A selection of immunosensor-based analytical platforms has also been developed for the detection of other bacterial pathogens, including Yersinia pestis, Vibrio cholerae, Mycobacterium tuberculosis and Brucella abortus (Table 4). Furthermore, an increase in public concern has resulted from the elevated numbers of nosocomial infections which have been caused by bacterial strains such as Clostridium difficile and methicillin-resistant S. aureus (MRSA). The latter bacterial strain produces 17 enterotoxins [2] and several immunosensor platforms have enabled the detection of Staphylococcal enterotoxin B (SEB). Harteveld and co-workers [104] developed a piezoelectric immunosensor for detecting $0.1 \mu \mathrm{g} / \mathrm{mL}$ of SEB through the development of a competition assay.

Table 4. Immunosensor-based detection of selected bacterial pathogens. Key: $[\mathrm{C}]$ - capture antibody; [S] - secondary antibody; [D] - detection antibody.

\begin{tabular}{|c|c|c|c|c|c|}
\hline $\begin{array}{c}\text { Bacterial } \\
\text { strain }\end{array}$ & $\begin{array}{c}\text { Biosensor } \\
\text { format }\end{array}$ & $\begin{array}{l}\text { Assay } \\
\text { format }\end{array}$ & Antibodies & Sensitivity & Ref. \\
\hline \multirow[t]{2}{*}{ B. anthracis } & Optical & Sandwich & $\begin{array}{l}\text { Biotinylated rabbit anti- } B \text {. anthracis } \\
\text { polyclonal }[\mathrm{C}] \text {; rabbit anti-B. anthracis } \\
\text { polyclonal CY5 [D] }\end{array}$ & $\begin{array}{c}3.2 \times 10^{5} \\
\text { spores/mg powder }\end{array}$ & {$[108]$} \\
\hline & Piezoelectric & Capture & Rabbit polyclonal anti- $B$. anthracis $[\mathrm{C}]$ & 333 spores $/ \mathrm{mL}$ & [109] \\
\hline B. globigii & Optical & Sandwich & $\begin{array}{l}\text { Goat anti- } B \text {. globigii }[\mathrm{C}] \text {; rabbit anti- } B \text {. } \\
\text { globigii }[\mathrm{S}] \text {; goat anti-rabbit-AP }[\mathrm{D}]\end{array}$ & 1 spore & {$[110]$} \\
\hline B. subtilis & Potentiometric & Sandwich & $\begin{array}{l}\text { Biotinylated polyclonal anti-B. subtilis } \\
\text { antibody [C]; fluorescein-labelled } \\
\text { polyclonal anti-B. subtilis antibody [S]; } \\
\text { anti-fluorescein urease-conjugated } \\
\text { antibody [D] }\end{array}$ & $3 \times 10^{3}$ spores $/ \mathrm{mL}$ & [111] \\
\hline F. tularensis & Magnetic & Sandwich & $\begin{array}{l}\text { Monoclonal anti- } F \text {. tularensis }[\mathrm{C}] \text {; } \\
\text { biotinylated monoclonal anti- } F \text {. tularensis } \\
\text { on streptavidin-coated magnetic beads }[\mathrm{D}]\end{array}$ & $\begin{array}{c}1 \times 10^{4}-1 \times 10^{6} \\
\mathrm{CFU} / \mathrm{mL}\end{array}$ & [112] \\
\hline \multirow[t]{2}{*}{ M. tuberculosis } & Piezoelectric & Capture & Rabbit anti-M. tuberculosis $[\mathrm{C}]$ & $1 \times 10^{5}$ cells $/ \mathrm{mL}$ & {$[113]$} \\
\hline & Voltammetric & Sandwich & $\begin{array}{l}\text { Biotinylated rabbit anti- } M \text {. tuberculosis } \\
{[\mathrm{C}] \text {; murine monoclonal anti- } M \text {. }} \\
\text { tuberculosis }[\mathrm{S}] \text {; rabbit anti-mouse-AP [D] }\end{array}$ & $1.0 \mathrm{ng} / \mathrm{mL}$ & {$[114]$} \\
\hline N. meningitidis & Optical & Direct & Murine anti-group $\mathrm{C}$ polysaccharide $[\mathrm{C}]$ & - & {$[115]$} \\
\hline \multirow[t]{2}{*}{ V. cholerae } & Amperometric & Sandwich & $\begin{array}{l}\text { Rabbit polyclonal anti- } V \text {. cholerae }[\mathrm{C}] \\
\text { mouse anti- } V \text {. cholerae }[\mathrm{S}] \text {; anti-mouse AP } \\
\text { [D] }\end{array}$ & $1 \times 10^{5}$ cells $/ \mathrm{mL}$ & {$[116]$} \\
\hline & Optical & Capture & Monoclonal anti- $V$. cholerae $\mathrm{O} 1[\mathrm{C}]$ & $\begin{array}{c}1 \times 10^{5}-1 \times 10^{9} \\
\text { cells } / \mathrm{mL}\end{array}$ & {$[117]$} \\
\hline$Y \cdot$ pestis & Magnetic & Sandwich & $\begin{array}{l}\text { Monoclonal anti-F1 antigen }[\mathrm{C}] \text {; } \\
\text { biotinylated monoclonal anti-F1 on } \\
\text { streptavidin-coated magnetic beads [D] }\end{array}$ & $2.5 \mathrm{ng} / \mathrm{mL}$ antigen & [118] \\
\hline
\end{tabular}


The capture of a rabbit polyclonal antibody on the sensor surface did not permit the detection of free SEB. The researchers, therefore, immobilised the toxin and subsequently passed over varying concentrations of antibody pre-incubated with the toxin. The response generated was inversely proportional to the concentration of free antigen in solution. A rapid (less than 10 minutes) fibre-optic SPR-based assay was also developed by Slavík et al. [105], capable of detecting $10 \mathrm{ng} / \mathrm{mL}$ of SEB. Immobilisation of antibodies (polyclonal) was facilitated by glutaraldehyde coupling. Moreno-Bondi and colleagues [106] reported that it was possible to detect femtogram (fg) quantities of human serum antibodies against SEB using an array biosensor (other antigens detected in this study included diphtheria toxin, hepatitis B surface antigen (HBsAg) and tetanus toxin), while a SPR-based assay, reported by Subramanian et al. [107] permitted the detection of whole $S$. aureus cells in direct and sandwich assay formats $\left(1 \times 10^{5} \mathrm{CFU} / \mathrm{mL}\right)$. The sensor format used in this assay was the Reichert SR7000, with alkane monothiol and dithiol dendritic tether-based SAMs used for the capture of polyclonal antibodies via EDC/NHS coupling.

\section{Immunosensors for Fungal Pathogens and Mycotoxins}

The detection of fungal strains is of great importance, due to their association with crop spoilage and their involvement as human pathogens, and immunosensor-based technologies have been developed for their determination.

A key consideration with analysing fungal cells relates to the fact that they are significantly larger than their bacterial counterparts, with fungal spores often over 40 micrometers in diameter [119]. This is understandably problematic in terms of system blockage. Hence, SIA assays, described earlier for bacterial strains $[28,103]$, may be used to circumvent this problem.

Skottrup et al. [120] pre-incubated a murine monoclonal antibody with sporangia of $P$. infestans at $37^{\circ} \mathrm{C}$ for 1 hour. The separation of bound and unbound antibody was permitted by a five minute centrifugation $(1500 \mathrm{~g})$. Free antibody was then passed over a surface containing bound goat-antimouse polyclonal antibody, allowing quantitation of free antibody. The limit of detection was $2.2 \times 10^{6}$ sporangia $/ \mathrm{mL}$, and no cross-reactivity was seen when other fungal strains, such as Melampsora euphorbia and Botrytis cinerea were assayed in parallel. A similar assay was also used to detect spores of Puccinia striiformis, using a polyclonal rabbit anti-mouse IgM antibody to capture a mouse monoclonal IgM antibody produced from immunisation with whole urediniospores. Completion of the resultant assay took approximately 45 minutes with a detection level of $3.1 \times 10^{5}$ urediniospores $/ \mathrm{mL}$ [121]. Additional immunosensor formats have also been used for the detection of human fungal pathogens. Muramatsu et al. [122] applied a piezoelectric sensor for detecting Candida albicans through the immobilisation of an anti-Candida antibody on a palladiumplated electrode. The recording of a loss in resonance frequency enabled the detection of $1 \times 10^{6} \mathrm{CFU} / \mathrm{cm}^{-3}$. Medyantseva and colleagues [123] targeted an antigenic determinant on Trichophyton rubrum with a polyclonal antiserum. Their amperometric immunoassay had a sensitivity of $1 \times 10^{-15} \mathrm{mg} / \mathrm{mL}$ of antigen and was rapid (20 minutes).

The monitoring of the presence of aflatoxins, naturally occurring mycotoxins produced by several strains of Aspergillus spp., in fruit, vegetable and food produce, is also of great significance. Aflatoxins can cause contamination of nuts (almonds, walnuts), cereals (rice, wheat, maize) and 
oilseeds (soybean and peanuts). While approximately 16 structurally diverse aflatoxins have been reported, aflatoxins $B_{1}, B_{2}, G_{1}$ and $G_{2}$ and $M_{1}$ (Figure 7) represent the greatest danger to human health [124]. Daly et al. [125] used a rabbit polyclonal antibody to detect $\mathrm{AFB}_{1}$, which was conjugated to BSA and immobilised onto a CM5 Biacore chip. A competition assay between free and bound AFB permitted a linear range of detection of trace levels $(3-98 \mathrm{ng} / \mathrm{mL})$. Daly and co-workers [126] subsequently generated murine scFvs against $\mathrm{AFB}_{1}$ by using a phage display format and incorporated these antibodies into a Biacore-based inhibition assay. Dunne et al. [127] also developed a SPR-based inhibition assay that incorporated monomeric and dimeric scFv antibody fragments for permitting the detection of between 390 and 12,000 ppb and 190 and 24,000 ppb of $\mathrm{AFB}_{1}$ with monomeric and dimeric scFvs, respectively. Adányi et al . [128] developed an optical wavelength lightmode spectroscopy (OWLS)-based assay for the detection of $\mathrm{AFB}_{1}$ and ochratoxin A. Integrated optical wavelength sensors were used in conjunction with murine monoclonal antibodies, with the sensitive detection range for a competitive assay being between 0.5 and $10 \mathrm{ng} / \mathrm{mL}$. An indirect screening protocol was subsequently applied for the detection of these toxins in wheat and barley samples.

Figure 7. Structures of commonly encountered aflatoxins.
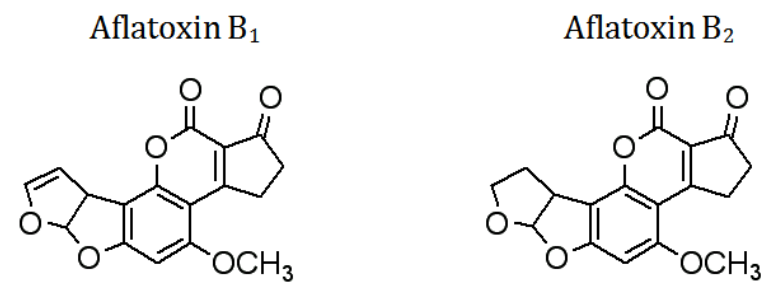

Aflatoxin $\mathrm{G}_{1}$

Aflatoxin $\mathrm{G}_{2}$

Aflatoxin $\mathrm{M}_{1}$<smiles>COc1cc2oc(=O)c3c(c2c2c1C1CCOC1O2)C(=O)OCC3</smiles><smiles>COc1cc2c(c3oc(=O)c4c(c13)CCC4=O)C1(O)C=COC1O2</smiles>

\section{Immunosensor Assays for the Detection of Viral Pathogens, Marine Toxins and Parasites}

The versatility of immunosensor-based analytical platforms for pathogen detection is further illustrated by the ability to develop assays for the sensitive detection of viral pathogens (Table 5). These include Hepatitis-C virus, the severe acute respiratory syndrome (SARS) virus and bovine diarrhoeal virus, whose particles present an additional selection of structurally diverse epitopes which can be targeted by antibodies. Single-celled phytoplankta play important roles in the aquatic environment by providing nourishment for a selection of heterotrophic marine animals. These include filter-feeding bivalve molluscs, such as mussels, clams and scallops. Among the reported 5,000 species of marine phytoplankton, 300 have been postulated to occur in high-numbers, causing harmful algal blooms (HABs) or 'red-tide' events. Approximately 40 of these species produce secondary metabolites, collectively referred to as phycotoxins [129], that are structurally diverse and nonproteinaceous compounds which have low molecular weights (in contrast to whole cell pathogens). 
They pose a considerable risk to human health by causing respiratory, neurological or gastrointestinal problems at low concentrations. The primary route of infection is through the ingestion of contaminated shellfish meat or drinking water. Furthermore, HABs also have a devastating effect on the shellfish industry and algal blooms can also result in reduced tourist activity and concomitant economic losses. Several countries have established regulations and specific concentration limits for phycotoxinlevelsin seafood [130].

Table 5. A selection of immunosensor-based assays for viral pathogen detection. Key: [C] - capture antibody; [P] - primary antibody; [S] - secondary antibody; [D] - detection antibody. Where primary antibodies are used, the antigen/epitope is immobilised on the sensor surface.

\begin{tabular}{|c|c|c|c|c|}
\hline Virus & $\begin{array}{l}\text { Biosensor } \\
\text { platform }\end{array}$ & $\begin{array}{l}\text { Assay } \\
\text { format }\end{array}$ & Antibodies & Ref. \\
\hline $\begin{array}{l}\text { Herpes simplex virus (HSV) } 1 \\
\text { and 2, Varicella-Zoster virus } \\
\text { (VSV), Cytomegalovirus (CMV) } \\
\text { and Epstein-Barr virus (EBV) }\end{array}$ & Piezoelectric & Capture & $\begin{array}{l}\text { Mouse monoclonal antibodies to herpes } \\
\text { simplex virus } 1 \text { and 2, cytomegalovirus, } \\
\text { Epstein-Barr virus and Varicella Zoster } \\
\text { virus [C] }\end{array}$ & {$[131]$} \\
\hline Foot and mouth virus (FMV) & Impedimetric & Indirect & Murine monoclonal $[\mathrm{P}]$ & {$[132]$} \\
\hline African swine fever virus (ASF) & Piezoelectric & Capture & Murine monoclonal $[\mathrm{C}]$ & [133] \\
\hline Bovine diarrhoeal virus (BVD) & Optoelectronic & Capture & Anti-BVD monoclonal & [134] \\
\hline $\begin{array}{l}\text { Cymbidium mosaic potexvirus } \\
\text { (CymMV) and Odontoglossum } \\
\text { ringspot tobamovirus (ORSV) }\end{array}$ & Piezoelectric & Capture & Rabbit polyclonal & {$[135]$} \\
\hline $\begin{array}{l}\text { SARS-associated coronavirus } \\
\text { (SARS-CoV) }\end{array}$ & Piezoelectric & Capture & Horse polyclonal anti-SARS-CoV $[\mathrm{C}]$ & {$[136]$} \\
\hline $\begin{array}{l}\text { Human immunodeficiency virus } \\
\text { (HIV-1) }\end{array}$ & Piezoelectric & Capture & $\begin{array}{l}\text { Murine anti-trans activator of transcription } \\
\text { (TAT) HIV [C] }\end{array}$ & [137] \\
\hline Hepatitis $\mathrm{C}$ virus $(\mathrm{HCV})$ & Optical & Indirect & $\begin{array}{l}\text { Polyclonal IgG antibodies [P]; Polyclonal } \\
\text { goat anti-human IgG-HRP [D] }\end{array}$ & [138] \\
\hline Cowpea mosaic virus (CPMV) & Optical & Capture & $\begin{array}{l}\text { Anti-CPMV recombinant antibody }(\mathrm{scFv}) \\
\text { fused to the constant light chain }\left(\mathrm{C}_{\mathrm{L}}\right) \\
\text { domain containing a } \mathrm{C} \text {-terminal cysteine } \\
\text { residue }[\mathrm{C}]\end{array}$ & [139] \\
\hline Ebola virus (EBOV) & Optical & Capture & $\begin{array}{l}\text { Mouse monoclonal anti-EBOV }[\mathrm{C}] \\
\text { Rabbit polyclonal antibody }[\mathrm{C}] \text { or Mouse } \\
\text { monoclonal antibody }[\mathrm{C}]\end{array}$ & {$[140]$} \\
\hline Avian leucosis virus (ALV) & Optical & Capture & Monoclonal anti-ALV-J & [141] \\
\hline Rift valley fever virus (RVF) & $\begin{array}{l}\text { Fibre optic } \\
\text { immunosensor }\end{array}$ & Sandwich & $\begin{array}{l}\text { Mouse polyclonal anti-RVF }[\mathrm{C}] \\
\text { Polyclonal IgG antibodies }[\mathrm{S}] \text {; Goat anti- } \\
\text { human IgG - HRP [D] }\end{array}$ & {$[142]$} \\
\hline West Nile virus (WNV) & Amperometric & Indirect & $\begin{array}{l}\text { Polyclonal IgG antibodies [P]; Goat anti- } \\
\text { human IgG-HRP [D] }\end{array}$ & [143] \\
\hline
\end{tabular}


Phycotoxin groups are classified according to the associated symptoms of infection, and a selection of structures is shown in Figure 8. Paralytic shellfish poisoning (PSP)-associated toxins are water soluble, thermostable tetrahydropurine molecules which are subdivided into four structural categories, namely carbamate, $N$-sulphocarbamoyl, decarbamoyl and dideoxycarbamoyl. The most commonly encountered PSP-causing toxins are gonyatoxin (GTX) and saxitoxin (STX). The latter is especially toxic, and over 20 structural analogues with differing degrees of toxicity have been reported in nature [144]. A causative agent of amnesic shellfish poisoning (ASP) is domoic acid, a potent kainoid neuro-excitatory toxin which is synthesised by the marine diatom Pseudo-nitzchia pungens [145] and functions by binding to specialised receptors and inducing depolarisation of neuronal cells.

Diarrheic shellfish poisoning (DSP) originates from the consumption of shellfish material contaminated with the polycyclic ether toxins okadaic acid (OA), dinophysis-toxin 1 (DTX1) and pectenotoxins (PTX). Yessotoxin (YTX) is also classified under this grouping as it was isolated in 1987 from scallops associated with a DSP-related poisoning event. However, it was noted that the pharmacological properties of YTX differed from those of DSP toxins [146]. Okadaic acid, DTX and PTX are all produced by dinoflagellates belonging to the Dinophysis and Prorocentrum species, whereas YTXs are synthesised by Protoceratium reticulatum [147]. Finally, cyanobacterial poisoning is caused by the hepatoxins microcystin (MC) and nodularin during red-tide events. Several bacterial species have been identified as being causative agents, including members of the geni Microcystis, Anaebaena and Planktothrix and consumption of contaminated water supplies is the primary route of infection [148].

Figure 8. Structures of commonly encountered phycotoxins.

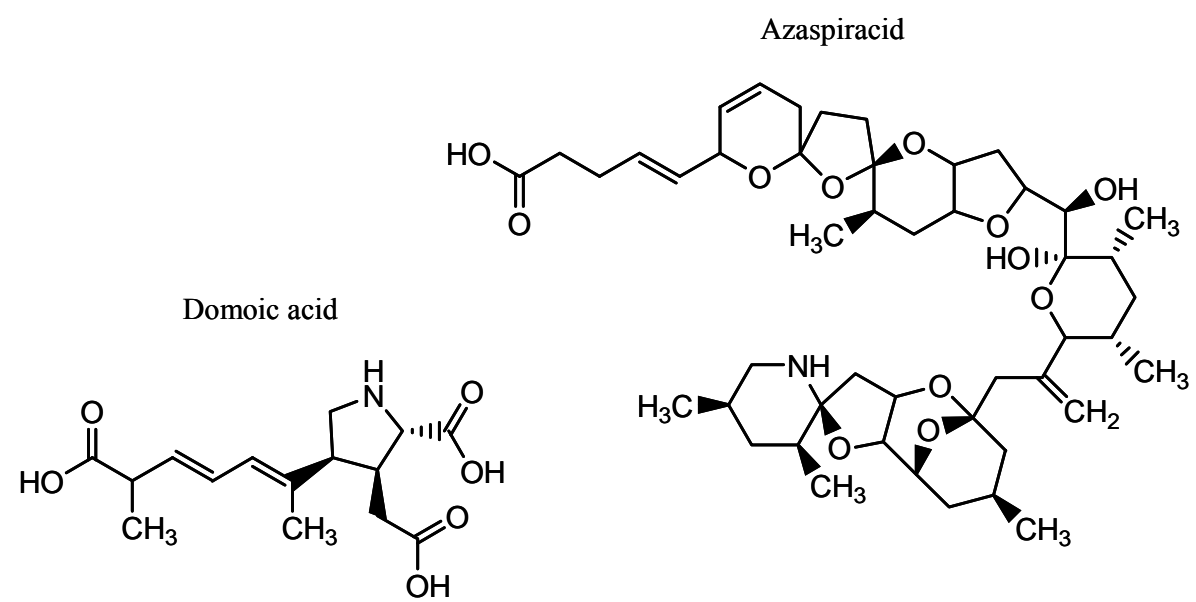

Okadaic acid

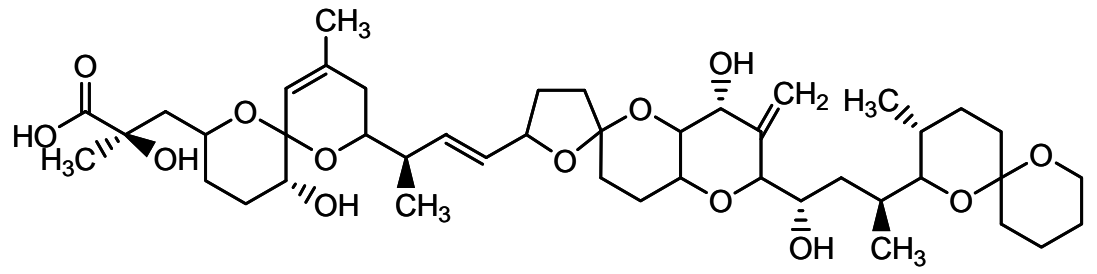

A small number of immunosensor-based formats for the monitoring of phycotoxins have been developed (Table 6), and these have mainly focussed on BTX, DA, MC, OA and STX. Several factors 
have contributed to this low number. A key factor is the scarcity of sufficiently pure toxin for antibody generation and the poor supply of reference material for assay development [149]. This has been problematic in the development of immunosensor-based assays for detecting other important marine toxins.

Azaspiracid (AZP) shellfish poisoning was first reported in 1995 in the Netherlands and was attributed to the consumption of mussels (Mytilus edulis) which were originally cultivated in Killary harbour, Ireland [163]. A total of 27 congeners of AZP have been characterised [164], and the producing strain has been postulated to be the dinoflagellate Protoperidinium spp. [165]. No antibodies have been developed against this target in its natural state, although an ELISA using an ovine polyclonal antibody against a synthetic AZA hapten was reported [166]. The availability of more reference material should permit additional assays to be developed for this and other marine toxins. Another important aspect for antibody-based marine algal toxin detection relates to the structural similarity that exists between toxin congeners. Furthermore, if a mixture of toxins is analysed in an immunosensor format, underestimation or overestimation of toxicity may occur as a result of an antibody being able to recognise multiple isomers of the same toxin molecule. This suggests that suitable antibody candidates have to be rigorously screened to ensure that cross-reactivity does not occur. Finally, biosensors for marine toxins should permit the detection of a toxin in a complex matrix, such as shellfish meat. The formats described in Table 6 were developed in an attempt to replace the current regulated methods of marine toxin detection, including the mouse bioassay and highperformance liquid chromatography-mass spectrometry (HPLC-MS). It remains to be seen whether they will be incorporated into legislation or routine monitoring programmes in the near future.

Table 6. A selection of immunosensor-based assays for marine algal toxin detection. Key: [C] capture antibody; [P] - primary antibody; [D] - detection antibody; LOD - limit of detection.

\begin{tabular}{lcllrl}
\hline \multicolumn{1}{c}{ Toxin } & $\begin{array}{c}\text { Biosensor } \\
\text { Format }\end{array}$ & $\begin{array}{c}\text { Assay } \\
\text { Format }\end{array}$ & \multicolumn{1}{c}{ Antibodies } & LOD & Ref \\
& Amperometric & Indirect & Goat-anti brevetoxin [P] & $15 \mu \mathrm{g} / \mathrm{L}$ & {$[150]$} \\
Brevetoxin & Amperometric & Indirect & Sheep polyclonal [P]; anti-sheep IgG-AP [D] & $2 \mu \mathrm{g} / \mathrm{L}$ & {$[151]$} \\
Domoic acid & Amperometric & Indirect & Rabbit polyclonal [P] & $0.1 \mu \mathrm{g} / \mathrm{L}$ & {$[152]$} \\
& Optical & Indirect & Monoclonal anti-DA [P] & $1.8 \mu \mathrm{g} / \mathrm{L}$ & {$[153]$} \\
& Optical & Indirect & Monoclonal anti-DA [P] & $0.1 \mu \mathrm{g} / \mathrm{L}$ & {$[154]$} \\
& Optical & Indirect & Rabbit polyclonal anti-DA [P] & $3 \mu \mathrm{g} / \mathrm{L}$ & {$[155]$} \\
& Optical & Direct & Monoclonal anti-MC-LR-Cy5 [P] & $0.03 \mu \mathrm{g} / \mathrm{L}$ & {$[156]$} \\
Microcystin-LR & Capacitance & Capture & Monoclonal anti-MC-LR [C] & $7 \mathrm{pg} / \mathrm{L}$ & {$[157]$} \\
(MC) & Optical & Direct & Monoclonal anti-MC-LR-Cy5 [P] & $30 \mathrm{ng} / \mathrm{L}$ & {$[158]$} \\
& Optical & Direct & Mouse monoclonal anti-OA-HRP [P] & $0.1 \mu \mathrm{g} / \mathrm{L}$ & {$[159]$} \\
Okadaic acid & Amperometric & Direct & Mouse monoclonal anti-OA-AP [P] & $1.5 \mu \mathrm{g} / \mathrm{L}$ & {$[151]$} \\
(OA) & Piezoelectric & Capture & Monoclonal anti-OA [C] & $3.6 \mu \mathrm{g} / \mathrm{L}$ & {$[160]$} \\
& Amperometric & Capture & Monoclonal anti-OA [C] & $2 \mu \mathrm{g} / \mathrm{L}$ & {$[161]$} \\
& Amperometric & Indirect & Mouse monoclonal anti-OA [P]; goat anti- & $0.03 \mu \mathrm{g} / \mathrm{L}$ & {$[162]$} \\
& & & mouse-HRP or AP [D] & & \\
Saxitoxin (STX) & Amperometric & Direct & Donkey anti-STX-glucose oxidase [P] & $2 \mu \mathrm{g} / \mathrm{L}$ & {$[150]$} \\
\hline
\end{tabular}


Immunosensor-based assay formats have allowed the detection of a selection of water-borne parasites. A piezoelectric assay was described by Campbell and Mutharasan [167] for the detection of between 100 and 10,000 oocysts/mL of Cryptosporidium parvum, while Kang and co-workers [168] developed a Biacore-based immunosensor assay which allowed the detection of between $1 \times 10^{2}-$ $1 \times 10^{6}$ oocysts $/ \mathrm{mL}$. The flexibility of using this methodology has also been illustrated by the ability to also detect other parasitic pathogens, including Schistosomajaponicum [169-172] and Borrelia burgdorferi [173], which act as causative agents of schistosomaisis and lyme borreliosis, respectively. These assays use amperometric [169-171], piezoelectric [172] and optical [173] -based platforms.

\section{Antibody-Based Biosensors: Potential Issues}

This review has outlined the principles and practices of antibody-based sensors for facilitating the detection of bacterial, fungal and viral species and toxins. A wide range of different applications have been highlighted involving the use of polyclonal and monoclonal antibodies (and, to a lesser extent, recombinant antibodies). However, it should also be emphasised that several problems may need to be addressed when developing related sensor-based assays, and these are now discussed.

Several of the aforementioned assays have also focused on a particular antigen. While this is also the most effective method for ensuring specificity, this may also be detrimental in instances where the exposure of a bacterial strain to stress, such as osmotic shock, alterations in $\mathrm{pH}$ or temperature fluctuations, or different growth media (e.g. different food matrices) may compromise the expression of a selective antigen. Hahm and Bhunia [174] exposed cells of L. monocytogenes, Salmonella spp. and E. coli $\mathrm{O} 157: \mathrm{H} 7$ to a variety of stress conditions and noted that antibody-based responses were reduced. Hearty and colleagues [6] heat-treated L. monocytogenes cells and assayed these alongside untreated cells on a monoclonal antibody-immobilised Biacore surface. A significant decrease in signal was observed when cells were treated at $60^{\circ} \mathrm{C}$ for 10 minutes, an observation putatively attributed to an alteration in the topography of the bacterial cell wall introduced by this treatment. These observations postulate that the sensitivity of an antibody may be compromised by an external factor, reiterating the importance of bacteriological propagation considerations. This point is particularly important in cases where antibodies are unable to differentiate between viable and nonviable cells, with active culturing able to circumvent this problem.

Several of the assays described in this review have been performed on SPR-based analytical platforms, and have involved the detection of bacterial and fungal cells whose sizes are typically between $1-5$ micrometers and in excess of 40 micrometers, respectively [119]. Capture formats are typically used, involving the immobilisation of an antibody and the subsequent capture of a cell and, if deemed necessary, the addition of secondary antibody to enhance sensitivity [89,101,102]. In Biacorebased analytical systems, the depth at which a SPR-produced evanescent wave can penetrate when TIR occurs is $0.3 \mu \mathrm{m}[28,101]$. Hence, the direct immobilisation of large bacteria and fungal cells, whose diameters exceed this area, might compromise detection. Conversely, in the cases where bacterial cells are captured on immobilised antibodies, the whole bacterial cell will not be contained within this area, implying that only a portion of the cell will be able to contribute towards a RI change. This observation may explain why shorter dextran chain lengths, such as those selected by Bokken 
et al. [102] (F1 or CM3 Biacore sensor chips) may be more suitable as, in theory, the bacterial cell is spatially arranged closer to the surface and, hence, is more exposed to the evanescent wave field.

It is also worth noting that Biacore detection systems typically monitor SPR angles on the sensor surface over an area of $0.25 \mathrm{~mm}^{2}$ [101]. This implies that a reduced SPR signal may arise from large cells sterically hindering each other if present in large amounts. This problem can be addressed by monitoring the sensor surface by atomic force microscopy (AFM), as discussed by Hearty et al . [6] who were able to undock a CM5 chip, containing L. monocytogenes cells bound to a monoclonal antibody, incubate overnight in a glutaraldehyde-cacodylate buffer and fix in the presence of osmium tetroxide. Dehydrated chips, treated with ethanol, could then be analysed to monitor surface topography. Finally, it is worth mentioning that ELISA and Biacore-based assays differ from each other in that the former typically involves a 'static' incubation of antibody and pathogen, while Biacore, and indeed several other assay formats, have additional considerations, including fluid forces. It is therefore of great importance that the antibody selected has sufficient affinity to allow cells to be captured and, most importantly, retained to permit further analysis [28]. This limitation effect can be overcome thorough the use of low flow-rates, such as $1 \mu \mathrm{L} /$ minute [6].

\section{Alternative Sensor-Based Platforms for Pathogen Detection}

Biomimetic sensors (e.g. 'electronic noses' and 'electronic tongues') and plant sensors can be selected as alternative methodologies to immunosensors for detecting pathogens. Electronic noses are comprised of sensor arrays that are capable of detecting a selection of compounds (e.g. ketones, aldehydes, aromatic and aliphatic compounds) produced during the growth stages of bacterial strains on a certain substrate. Needham and colleagues [175] were able to detect one bacterial (B. subtilis) and two fungal strains (Penicillium verrucosum, Pichia anomala) on bread before visible signs of spoilage were observed. Lipoxygenase-based enzymatic spoilage could also be differentiated from microbial spoilage, and this methodology was coupled with gas chromatography-mass spectrometry (GC-MS) for characterisation of the 'volatiles' (e.g. 1-butanol, 2-butanone) produced during growth of these strains. Alocilja et al. [176] were able to differentiate strains of E. coli O157:H7 from unrelated E. coli strains by monitoring the gaseous products produced when cells were propagated in a nutrient broth liquid culture. The electronic nose-based sensor chamber incorporated four metal-oxide gas sensors for the detection of volatile products of E. coli growth, such as amines, ketones and alcohols. This investigation allowed the researchers to demonstrate that E. coli $\mathrm{O} 157: \mathrm{H} 7$ had a different gas signature pattern from the unrelated strains tested in parallel. Furthermore, Balasubramanian and co-workers were able to detect $S$. typhimurium in spiked vacuum-packed beef striploins (2.6 CFU/g beef) [177]. In contrast, electronic tongues focus on the analysis of liquid samples, and are applicable for the analysis of food quality [178]. This biomimetic sensor format was selected by Lan and colleagues for the detection of $S$. typhimurium $\left(1 \times 10^{6} \mathrm{CFU} / \mathrm{mL}\right)$ in chicken carcass samples [179].

Non-antibody biomimetic receptor molecules, including engineered proteins, peptides, aptamers (single stranded DNA or RNA), ribozymes or synzymes (synthetic enzymes), also have potential in the detection of pathogens and other food contaminants [180]. A piezoelectric biosensor using oligopeptides designed to mimic the binding site of the aryl hydrocarbon receptor (dioxin receptor) protein was used to sensitively detect dioxins $(1-20 \mathrm{ppb})$ [181]. Similarly, surface-immobilised 
antimicrobial peptides (e.g. polymyxins B and E) were used to detect $S$. typhimurium $\left(5 \times 10^{4}\right)$ and $E$. coli $\mathrm{O} 157: \mathrm{H} 7\left(1 \times 10^{5} \mathrm{CFU} / \mathrm{mL}\right)$ in direct and sandwich assay formats [182]. Pan et al. [183] reported the successful detection of $S$. enterica serovar Typhi by using a single-stranded RNA aptamer $\left(\mathrm{S}-\mathrm{PS}_{8.4}\right)$ that bound to pili (type IVB) expressed on the bacterial cell that were instrumental in promoting pathogenesis.

The ability of plants sensors (phytosensors) to detect environmental conditions and plant pathogens is still in its infancy in terms of sensor technology. A phytosensor capable of detecting plant pathogens at the molecular level was described by Mazarei and co-workers [184]. Transgenic tobacco plants, containing an inducible plant defense mechanism linked to the $\beta$-glucuronidase reporter gene, inoculated with Alfalfa mosaic virus showed increased $\beta$-glucuronidase expression.

These examples demonstrate that the combination of synthetic receptors mimicking nature with desired transducers can be selected as an alternative to immunosensor-based analysis for pathogen detection, although further development will be needed before these alternative formats are selected above immunosensor platforms for pathogen analysis.

\section{Conclusions}

The importance of antibodies as biorecognition elements for pathogen detection was discussed. Antibody-based sensors can provide robust, sensitive and rapid analysis. In most cases the key element is the quality of the antibody used and recombinant antibodies have many advantages, including the ability to be genetically modified to improve selectivity, sensitivity and immobilisation. In practice, the development of these assays is simplified through the development of a suitable antibody and, subsequently, an assay format. While there are several problems associated with these methods, the potential for monitoring bacterial, fungal, viral and parasitic pathogens is immense.

Innovative recent developments, such as the hand-held device described recently by Mujika et al. [85], signal the way forward for pathogen detection. Future trends will continue to implement immunosensor-based technologies into microdevices, ultimately permitting on-site analysis to be performed in a rapid, reliable and sensitive manner.

\section{Acknowledgements}

The financial support of the Centre for Bioanalytical Sciences (CBAS), the Biomedical Diagnostics Institute (BDI), Dublin City University, the Industrial Developmental Agency (IDA), Ireland, Science Foundation Ireland (SFI), grant no. 05/CE3/B754, Enterprise Ireland (EI), the Marine Institute and Beaufort Marine Initiative, Safefood Biotoxin Research Network and the European Union $7^{\text {th }}$ Framework programme (Research for benefit of Small Medium Enterprise, grant No. 232037) is gratefully acknowledged.

\section{References and Notes}

1. Gracias, K.S.; McKillip, J.L. A review of conventional detection and enumeration methods for pathogenic bacteria in food. Can. J. Microbiol. 2004, 50, 883-890. 
2. Bhunia, A.K. Biosensors and bio-based methods for the separation and detection of foodborne pathogens. Adv. Food Nutr. Res. 2008, 54, 1-44.

3. Leonard, P.; Hearty, S.; Brennan, J.; Dunne, L.; Quinn, J.; Chakraborty, T.; O’Kennedy, R. Advances in biosensors for detection of pathogens in food and water. Enzyme Microb. Tech. 2003, 32, 3-13.

4. Available online: www.oxoid.com/UK/blue/orgbrowse/orgbrowse.asp, Accession date: May 6, 2009.

5. Kim, H.; Bhunia, A.K. SEL, a selective enrichment broth for simultaneous growth of Salmonella enterica, Escherichia coli O157:H7 and Listeria monocytogenes. Appl. Environ. Microbiol. 2008, 74, 4853-4866.

6. Hearty, S.; Leonard, P.; Quinn, J.; O'Kennedy, R. Production, characterisation and potential application of novel monoclonal antibody for rapid identification of virulent Listeria monocytogenes. J. Microbiol. Methods 2006, 66, 294-312.

7. De Boer, E.; Beumer, R.R. Methodology for detection and typing of foodborne microorganisms. Int. J. Food Microbiol. 1999, 50, 119-130.

8. O’Grady, J.; Ruttledge, M.; Sedano-Balbás, S.; Smith, T.J.; Barry, T.; Maher, M. Rapid detection of Listeria monocytogenes in food using culture enrichment combined with real-time PCR. Food Microbiol. 2009, 26, 4-7.

9. Brooks, B.W.; Devenish, J.; Lutze-Wallace, C.L.; Milnes, D.; Robertson, R.H.; Berlie-Surujballi, G. Evaluation of a monoclonal antibody-based enzyme-linked immunosorbent assay for the detection of Campylobacter fetus in bovine preputial washing and vaginal mucus samples. Vet. Microbiol. 2004, 103, 77-84.

10. Dreux, N.; Albagnac, C.; Federighi, M.; Carlin, F.; Morris, C.E.; Nguyen-The, C. Viable but nonculturable Listeria monocytogenes on parsley leaves and absence of recovery to a culturable state. J. Appl. Microbiol. 2007, 103, 1272-1281.

11. Asakura, H.; Panutdaporn, N.; Kawamoto, K.; Igimi, S.; Yamamoto, S.; Makino, S. Proteomic characterization of enterohemorrhagic Escherichia coli $\mathrm{O} 157: \mathrm{H} 7$ in the oxidation-induced viable but non-culturable state. Microbiol. Immunol. 2007, 51, 875-881.

12. Uyttendaele, M.; Schukkink, R.; van Gemen, B.; Debevere, J. Development of NASBA, a nucleic acid amplification system, for identification of Listeria monocytogenes and comparison to ELISA and a modified FDA method. Int. J. Food Microbiol. 1995, 27, 77-89.

13. Nadal, A.; Coll, A.; Cook, N.; Pla, M. A molecular beacon-based real time NASBA assay for detection of Listeria monocytogenes in food products: Role of target mRNA secondary structure on NASBA design. J. Microbiol. Methods 2007, 68, 623-632.

14. Toze, S. PCR and the detection of microbial pathogens in water and wastewater. Water Res. 1999, 33, 3545-3556.

15. Rodríguez-Lázaro, D.; D’Agostino, M.; Herrewegh, A.; Pla, M.; Cook, N.; Ikonomopoulos, J. Real-time PCR-based methods for detection of Mycobacterium avium subsp. Paratuberculosis in water and milk. Int. J. Food Microbiol. 2005, 101, 93-104.

16. Fu, Z.; Rogelj, S.; Kieft, T.L. Rapid detection of Escherichia coli O157:H7 by immunomagnetic separation and real-time PCR. Int. J. Food Microbiol. 2005, 99, 47-57. 
17. Renwick, L.; Hardie, A.; Girvan, E.K.; Smith, M.; Leadbetter, G.; Claas, E.; Morrison, D.; Gibb, A.P.; Dave, J.; Templeton, K.E. Detection of methicillin-resistant Staphylococcus aureus and Panton-Valentine leukocidin directly from clinical samples and the development of a multiplex assay using real-time polymerase chain reaction. Eur. J. Clin. Microbiol. Infect. Dis. 2008, 27, 791-796.

18. Rodríguez-Lázaro, D.; Jofré, A.; Aymerich, T.; Hugas, M.; Pla, M. Rapid quantitative detection of Listeria monocytogenes in meat products by real-time PCR. Appl. Environ. Microbiol. 2004, 70, 6299-6301.

19. Park, H.J.; Kim, H.J.; Park, S.H.; Shin, E.G.; Kim. J.H.; Kim, H.Y. Direct and quantitative analysis of Salmonella enterica serovar Typhimurium using real-time PCR from artificially contaminated chicken meat. J. Microbiol. Biotechnol. 2008, 18, 1453-1458.

20. Wang, L.; Li, Y.; Mustaphai, A. Rapid and simultaneous quantitation of Escherichia coli O157:H7, Salmonella, and Shigella in ground beef by multiplex real-time PCR and immunomagnetic separation. J. Food Prot. 2007, 70, 1366-1372.

21. Jofré, A.; Martin, B.; Garriga, M.; Hugas, M.; Pla, D.; Rodríguez-Lázaro, D.; Aymerich, T. Simultaneous detection of Listeria monocytogenes and Salmonella by multiplex PCR in cooked ham. Food Microbiol. 2005, 22, 109-115.

22. Gómez-Duarte, O.G.; Bai, J.; Newell, E. Detection of Escherichia coli, Salmonella spp., Shigella spp., Yersinia enterocolitica, Vibrio cholerae and Campylobacter spp. enteropathogens by 3reaction multiplex polymerase chain reaction. Diagn. Microbiol. Infect. Dis. 2009, 63, 1-9.

23. Yaron, S.; Matthews, K.R. A reverse transcriptase-polymerase chain reaction assay for detection of viable Escherichia coli O157:H7: Investigation of specific target genes. J. Appl. Microbiol. 2002, 92, 633-640.

24. Morin, N.J.; Gong, Z.; Li, X.F. Reverse transcription-multiplex PCR assay for simultaneous detection of Escherichia coli O157:H7, Vibrio cholerae O1, and Salmonella typhi. Clin. Chem. 2004, 50, 2037-2044.

25. Liang, H.; Cordova, S.E.; Kieft, T.L.; Rogelj, S. A highly sensitive immuno-PCR assay for detecting group A Streptococcus. J. Immunol. Methods 2003, 279, 101-110.

26. Zhang, W.; Bielaszewska, M.; Pulz, M.; Becker, K.; Friedrich, A.W.; Karch, H.; Kuczius, T. New immuno-PCR assay for detection of low concentrations of shiga toxin 2 and its variants. J. Clin. Microbiol. 2008, 46, 1292-1297.

27. Cook, N. The use of NASBA for the detection of microbial pathogens in food and environmental samples. J. Microbiol. Methods 2003, 53, 165-174.

28. Leonard, P.; Hearty, S.; Quinn, J.; O'Kennedy, R. A generic approach for the detection of whole Listeria monocytogenes cells in contaminated samples using surface plasmon resonance. Biosens. Bioelectron. 2004, 19, 1331-1335.

29. Leenaars, M.; Hendricksen, C.F.M. Critical steps in the production of polyclonal and monoclonal antibodies: Evaluation and recommendations. ILAR J. 2005, 46, 269-279.

30. Arnold, J.N.; Wormald, M.R.; Sim, R.B.; Rudd, P.M.; Dwek, R.A. The impact of glycosylation on the biological function and structure of human immunoglobulins. Annu. Rev. Immunol. 2007, 25, 21-50. 
31. Köhler, G.; Milstein, C. Continuous cultures of fused cells secreting antibody of predefined specificity. Nature (London) 1975, 256, 495-497.

32. Nelson, P.N.; Reynolds, G.M.; Waldron, E.E.; Ward, E.; Giannopoulos, K.; Murray, P.G. Monoclonal antibodies. Mol. Pathol. 2000, 53, 111-117.

33. Bradbury, A.R.; Marks, J.D. Antibodies from phage antibody libraries. J. Immunol. Methods 2004, 290, 29-49.

34. Hoogenboom, H.R. Selecting and screening recombinant antibody libraries. Nat. Biotechnol. 2005, 23, 1105-1116.

35. Finlay, W.J.; deVore, N.C.; Dobrovolskaia, E.N.; Gam, A.; Goodyear, C.S.; Slater, J.E. Exploiting the avian immunoglobulin system to simplify the generation of recombinant antibodies to allergenic proteins. Clin. Exp. Allergy 2005, 35, 1040-1048.

36. Townsend, S.; Finlay, W.J.; Hearty, S.; O’Kennedy, R. Optimising recombinant antibody function in SPR immunosensing. The influence of antibody structural format and chip surface chemistry on assay sensitivity. Biosens. Bioelectron. 2006, 22, 268-274.

37. Sakai, K.; Shimizu, Y.; Chiba, T.; Matsumoto-Takasaki, A.; Kusada, Y.; Zhang, W.; Nakata, M.; Kojima, N.; Toma, K.; Takayanagi, A.; Shimizu, N.; Fujita-Yamaguchi, Y. Isolation and characterisation of phage-displayed single chain antibodies recognizing nonreducing terminal mannose residues. 1. A new strategy for generation of anti-carbohydrate antibodies. Biochemistry 2007, 46, 253-262.

38. Andris-Widhopf, J.; Steinberger, P.; Fuller, R.; Rader, C.; Barbas, C.F. III. Generation of antibody libraries: PCR amplification and assembly of light- and heavy-chain coding sequences. In Phage display: A laboratory manual , 1st Ed.; Barbas, C.F., Burton, D.R., Scott, J.K., Silverman, G.J., Eds.; Cold Spring Harbor Laboratory Press: New York, NY, USA, 2001; pp. 9.1-9.113.

39. Hoogenboom, H.R.; Griffiths, A.D.; Johnson, K.S.; Chiswell, D.J.; Hudson, P.; Winter, G. Multisubunit proteins on the surface of filamentous phage: Methodologies for displaying antibody (Fab) heavy and light chains. Nucleic Acids Res. 1991, 19, 4133-4137.

40. Maynard, J.; Georgiou, G. Antibody engineering. Annu. Rev. Biomed. Eng. 2000, 2, 339-376.

41. Hudson, P.J.; Souriau, C. Engineered antibodies. Nat. Med. 2003, 9, 129-134.

42. Leonard, P.; Säfsten, P.; Hearty, S.; McDonnell, B.; Finlay, W.; O’Kennedy. R. High throughput ranking of recombinant avian $\mathrm{scFv}$ antibody fragments from crude lysates using the Biacore A100. J. Immunol. Methods 2006, 323, 172-179.

43. Lee, Y.C.; Leu, S.J.; Hu, C.J.; Shih, N.Y.; Huang, I.J.; Wu, H.H.; Hsieh, W.S.; Chiang, B.L.; Chiu, W.T.; Yang, Y.Y. Chicken single-chain variable fragments against the SARS-CoV spike protein. J. Virol. Methods 2007, 146, 104-111.

44. Torensma, R.; Visser, M.J.C.; Aarsman, C.J.M.; Poppelier, M.J.J.G.; Fluit, A.C.; Verhoef, J. Monoclonal antibodies that react with live Listeria spp. Appl. Environ. Microbiol. 1993, 59, 2713-2716.

45. Uyttendaele, M.; Van Hoorde, I.; Debevere, J. The use of immuno-magnetic separation (IMS) as a tool in a sample preparation method for direct detection of L. monocytogenes in cheese. Int. J. Food Microbiol. 2000, 54, 205-212.

46. Jordan, D.; Vancov, T.; Chowdhury, A.; Andersen, L.M.; Jury, K.; Stevenson, A.E.; Morris, S.G. The relationship between concentration of a dual marker strain of Salmonella typhimurium in 
bovine faeces and its probability of detection by immunomagnetic separation and culture. J. Appl. Microbiol. 2004, 97, 1054-1062.

47. Chapman, P.A.; Ashton, R. An evaluation of rapid methods for detecting Escherichia coli 0157 on beef carcasses. Int. J. Food Microbiol. 2003, 87, 279-285.

48. Kerr, P.; Finlay, D.; Thomson-Carter, F.; Ball, H.J. A comparison of a monoclonal antibody-based sandwich ELISA and immunomagnetic bead selective enrichment for the detection of Escherichia coli $\mathrm{O} 157$ from bovine faeces. J. Appl. Microbiol. 2001, 91, 933-936.

49. Kerr, P.; Chart, H.; Finlay, D.; Pollock, D.A.; MacKie, D.P.; Ball, H.J. Development of a monoclonal sandwich ELISA for the detection of animal and human Escherichia coli O157 strains. J. Appl. Microbiol. 2001, 90, 543-549.

50. Kim, S.H.; Park, M.K.; Kim, J.Y.; Chuong, P.D.; Lee. Y.S.; Yoon, B.S.; Hwang, K.K.; Lim, Y.K. Development of a sandwich ELISA for the detection of Listeria spp. using specific flagella antibodies. J. Vet. Sci. 2005, 6, 41-46.

51. Tully, E.; Hearty, S.; Leonard, P.; O'Kennedy, R. The development of rapid fluorescence-based immunoassays, using quantum dot-labelled antibodies for the detection of Listeria monocytogenes cell surface proteins. Int. J. Biol. Macromol. 2006, 39. 127-134.

52. Valdivieso-Garcia, A.; Riche, E.; Abubakar, O.; Waddell, T.E.; Brooks, B.W. A double antibody sandwich enzyme-linked immunosorbent assay for the detection of Salmonella using biotinylated monoclonal antibodies. J. Food Prot. 2001, 64, 1166-1171.

53. MacBeath, G.; Schreiber, S.L. Printing proteins as microarrays for high-thoughput function determination. Science 2000, 289, 1760-1763.

54. Gehring, A.G.; Albin, D.M.; Bhunia, A.K.; Reed, S.A.; Tu, S.I.; Uknalis, J. Antibody microarray detection of Escherichia coli O157:H7: Quantification, assay limitations, and capture efficiency. Anal. Chem. 2006, 78, 6601-6607.

55. Cai, H.Y.; Lu, L.; Muckle, C.A.; Prescott, J.F.; Chen, S. Development of a novel protein microarray for serotyping Salmonella enterica strains. J. Clin. Microbiol. 2005, 43, 3427-3430.

56. Anjum, M.F.; Tucker, J.D.; Sprigings, K.A.; Woodward, M.J.; Ehricht, R. Use of miniaturized protein arrays for Escherichia coli O serotyping. Clin. Vaccine Immunol. 2006, 13, 561-567.

57. Gehring, A.G.; Albin, D.M.; Reed, S.A.; Tu, S.I.; Brewster, J.D. An antibody microarray, in multiwall plate format, for multiplex screening of foodborne pathogenic bacteria and biomolecules. Anal. Bioanal. Chem. 2008, 391, 497-506.

58. Huelseweh, B.; Ehricht, R.; Marschall, H.J. A simple and rapid protein array based method for the simultaneous detection of biowarfare agents. Proteomics 2006, 6, 2972-2981.

59. Sapsford, K.E.; Ngundi, M.M.; Moore, M.H.; Lassman, M.E.; Shriver-Lake, L.C.; Taitt, C.R.; Ligler, F.S. Rapid detection of foodborne contaminants using an array biosensor. Sens. Act. B 2006, 113, 599-607.

60. Delehanty, J.B.; Ligler, F.S. A microarray immunoassay for simultaneous detection of proteins and bacteria. Anal. Chem. 2002, 74, 5681-5687.

61. Palchetti, I.; Mascini, M. Electrochemical biosensors and their potential for food pathogen and toxin detection. Anal. Bioanal. Chem. 2008, 391, 455-471. 
62. Gehring, A.G.; Crawford, C.G.; Mazenko, R.S.; Van Houten, L.J.; Brewster, J.D. Enzyme-linked immunomagnetic electrochemical detection of Salmonella typhimurium. J. Immunol. Methods 1996, 195, 15-25.

63. Ivnitski, D.; Wilkins, E.; Tien, H.T.; Ottova, A. Electrochemical biosensor based on supported planar lipid bilayers for fast detection of pathogenic bacteria. Electrochem. Comm. 2000, 2, 457-460.

64. Lin, Y.H.; Chen, S.H.; Chuang, Y.C.; Lu, Y.C.; Shen, T.Y.; Chang, C.A.; Lin, C.S. Disposable amperometric immunosensing strips fabricated by $\mathrm{Au}$ nanoparticles-modified screen-printed carbon electrodes for the detection of foodborne pathogen Escherichia coli O157:H7. Biosens. Bioelectron. 2008, 23, 1832-1837.

65. Crowley, E.L.; O'Sullivan, C.K.; Guilbault, G.G. Increasing the sensitivity of Listeria monocytogenes assays: Evaluation using ELISA and amperometric detection. Analyst 1999, 124, 295-299.

66. Ivnitski, D.; Abdel-Hamid, I.; Atanasov, P.; Wilkins, E.; Striker, S. Application of electrochemical biosensors for detection of food pathogenic bacteria. Electroanalysis 2000, 12, 317-325.

67. Radke, S.M.; Alocilja, E.C. A high density microelectrode array biosensor for detection of E. coli O157:H7. Biosens. Bioelectron. 2005, 20, 1662-1667.

68. Tully, E.; Higson, S.P.; O'Kennedy, R. The development of a 'labeless' immunosensor for the detection of Listeria monocytogenes cell surface protein, Internalin B. Biosens. Bioelectron. 2008, 23, 906-912.

69. Wang, R.; Ruan, C.; Kanayeva, D.; Lassiter, K.; Li, Y. $\mathrm{TiO}_{2}$ nanowire bundle microelectrodebased impedance immunosensor for rapid and sensitive detection of Listeria monocytogenes . Nano Lett. 2008, 8, 2625-2631.

70. Su, X.L.; Li, Y. A QCM immunosensor for Salmonella detection with simultaneous measurements of resonant frequency and motional resistance. Biosens. Bioelectron. 2005, 21, 840-848.

71. Gehring, A.G.; Patterson, D.L.; Tu, S.I. Use of a light-addressable potentiometric sensor for the detection of Escherichia coli O157:H7. Anal. Biochem. 1998, 258, 293-298.

72. Dill, K.; Stanker, L.H.; Young, C.R. Detection of Salmonella in poultry using a silicon chip-based biosensor. J. Biochem. Biophys. Methods 1999, 41, 61-67.

73. Hoa, D.T.; Suresh Kumar, T.N.; Pnuekar, N.S.; Srinivasa, R.S.; Lal, R.; Contractor, A.Q. A biosensor based on conducting polymers. Anal. Chem. 1992, 64, 2645-2646.

74. Muhammad-Tahir, Z.; Alocilja, E.C. A conductimetric biosensor for biosecurity. Biosens. Bioelectron. 2003, 18, 813-819.

75. Muhammad-Tahir, Z.; Alocilja, E.C. A disposable biosensor for pathogen detection in fresh produce. Biosyst. Eng. 2004, 88, 145-151.

76. Hnaiein, M.; Hassen, W.M.; Abdelghani, A.; Fournier-Wirth, C.; Coste, J.; Bessueille, F.; Leonard, D.; Jaffrezic-Renault, N. A conductometric immunosensor based on functionalised magnetite nanoparticles for E. coli detection. Electrochem. Commun. 2008, 10, 1152-1154.

77. Ngeh-Ngwainbi, J.; Suleiman, A.A.; Guilbault, G.G. Piezoelectric crystal biosensors. Biosens. Bioelectron. 1990, 5, 13-26. 
78. Su, X.L.; Li, Y. A self-assembled monolayer-based piezoelectric immunosensor for rapid detection of Escherichia coli O157:H7. Biosens. Bioelectron. 2004, 19, 563-574.

79. Babacan, S.; Pivarnik, P.; Lecter, S.; Rand, A.G. Evaluation of antibody immobilization methods for piezoelectric biosensor application. Biosens. Bioelectron. 2000, 15, 615-621.

80. Fung, Y.S.; Wong, Y.Y. Self-assembled monolayers as the coating in a quartz piezoelectric crystal immunosensor to detect Salmonella in aqueous solution. Anal. Chem. 2001, 73, 53025309.

81. Kim, G.H.; Rand, A.G.; Letcher, S.V. Impedance characterization of a piezoelectric immunosensor part II: Salmonella typhimurium detection using magnetic enhancement. Biosens. Bioelectron. 2003, 18, 91-99.

82. Pohanka, M.; Skládal, P.; Pavlis, O. Label-free piezoelectric immunosensor for rapid assay of Escherichia coli. J. Immunoassay Immunochem. 2008, 29, 70-79.

83. Ramanathan, K.; Danielsson, B. Principles and applications of thermal biosensors. Biosens. Bioelectron. 2001, 16, 417-423.

84. Ruan, C.; Zeng, K.; Varghese, O.K.; Grimes, C.A. Magnetoelastic immunosensors: Amplified mass immunosorbent assay for detection of Escherichia coli O157:H7. Anal. Chem. 2003, 75, 6494-6498.

85. Mujika, M.; Arana, S.; Castaño, E.; Tijero, M.; Vilares, R.; Ruano-López, J.M.; Cruz, A.; Sainz, L.; Berganza, J. Magnetoresistive immunosensor for the detection of Escherichia coli O157:H7 including a microfluidic network. Biosens. Bioelectron. 2009, 24, 1253-1258.

86. Kretschmann, E.; Raether, H. Radiative decay of non-radiative surface plasmons excited by light. Z. Naturforsch. 1968, 23, 2135-2136.

87. Kretschmann, E. The determination of optical constants of metals by excitation of surface plasmon resonance. Z. Phys. 1971, 241, 313-324.

88. Wei, D.; Oyarzabal, O.A.; Huang, T.S.; Balasubramanian, S.; Sista, S.; Simonian, A.L. Development of a surface plasmon resonance biosensor for the identification of Campylobacter jejuni. J. Microbiol. Methods 2007, 69, 78-85.

89. Barlen, B.; Mazumdar, S.D.; Lezrich, O.; Kämpfer, P.; Keugsen, M. Detection of Salmonella by surface plasmon resonance. Sensors 2007, 7, 1427-1446.

90. Mazumdar, S.D.; Hartmann, M.; Kämpfer, P.; Keugsen, M. Rapid method for detection of Salmonella in milk by surface plasmon resonance. Biosens. Bioelectron. 2007, 22, 2040-2046.

91. Oh, B.K.; Lee, W.; Chun, B.S.; Bae, Y.M.; Lee, W.H.; Choi, J.W. The fabrication of protein chip based on surface plasmon resonance for detection of pathogens. Biosens. Bioelectron. 2005, 20, 1847-1850.

92. Koubová, V.; Brynda, E.; Karasová, L.; Škvor, J.; Homola, J.; Dostálek, J.; Tobiška, P.; Rošicky, J. Detection of foodborne pathogens using surface plasmon resonance biosensors. Sens. Act. B 2001, 74, 100-105.

93. Taylor, A.D.; Ladd, J.; Yu, Q.; Chen, S.; Homola, J.; Jiang, S. Quantitative and simultaneous detection of four foodborne bacterial pathogens with a multi-channel SPR sensor. Biosens. Bioelectron. 2006, 22, 752-758. 
94. Rijal, K.; Leung, A.; Mohana Shankar, P.; Mutharasan, R. Detection of pathogenic Escherichia coli $\mathrm{O} 157: \mathrm{H} 7$ at 70 cells $/ \mathrm{mL}$ using antibody-immobilized biconical tapered fiber sensors. Biosens. Bioelectron. 2005, 21, 871-880.

95. Donaldson, K.A.; Kramer, M.F.; Lim, D.V. A rapid detection method for Vaccinia virus, the surrogate for smallpox virus. Biosens. Bioelectron. 2004, 20, 322-327.

96. Lim, D.V. Detection of microorganisms and toxins with evanescent wave fiber-optic biosensors. Proc. IEEE 2003, 91, 902-907.

97. Anderson, G.P.; Nerurkar, N.L. Improved fluoroimmunoassays using the dye Alexa Fluor 647 with the RAPTOR, a fiber optic biosensor. J. Immunol. Methods 2002, 271, 17-24.

98. Kramer, M.F.; Lim, D.V. A rapid and automated fiber optic-based biosensor assay for the detection of Salmonella in spent irrigation water used in the sprouting of sprout seeds. J. Food Prot. 2004, 67, 46-52.

99. Nanduri, V.; Kim, G.; Morgan, M.T.; Ess, D.; Hahm, B.K.; Kothapalli, A.; Valadez, A.; Geng, T.; Bhunia, A.K. Antibody immobilization on waveguides using a flow-through system shows improved Listeria monocytogenes detection in an automated fiber optic biosensor: RAPTOR ${ }^{\mathrm{TM}}$. Sensors 2006, 6, 808-822.

100. Leskinen, S.D.; Lim, D.V. Rapid ultrafiltration concentration and biosensor detection of Enterococci from large volumes of Florida recreational water. Appl. Env. Microbiol. 2008, 74, 4792-4798.

101. Fratamico, P.M.; Strobaugh, T.P.; Medina, M.B.; Gehring, A.G. Detection of Escherichia coli O157:H7 using a surface plasmon resonance biosensor. Biotechnol. Techn. 1998, 12, 571-576.

102. Bokken, G.C.; Corbee, R.J.; van Knapen, F.; Bergwerff, A.A. Immunochemical detection of Salmonella group B, D and E using an optical surface plasmon resonance biosensor. FEMS Microbiol. Lett. 2003, 222, 75-82.

103. Haines, J.; Patel, P.D. Detection of food borne pathogens using BIA. BIA J. 1995, $2,31$.

104. Harteveld, J.L.N.; Nieuwenhuizen, M.S. and Wils, E.R.J. Detection of Staphylococcal enterotoxin B employing a piezoelectric crystal immunosensor. Biosens. Bioelectron. 1997, 12, 661-667.

105. Slavík, R.; Homola, J.; Brynda, E. A miniature fiber optic surface plasmon resonance sensor for fast detection of Staphylococcal enterotoxin B. Biosens. Bioelectron. 2002, 17, 591-595.

106. Moreno-Bondi, M.C.; Rowe-Taitt, C.; Shriver-Lake, L.C.; Ligler, F.S. Multiplexed measurement of serum antibodies using an array biosensor. Biosens. Bioelectron. 2006, 21, 1880-1886.

107. Subramanian, A.; Irudayaraj, J.; Ryan, T. Mono and dithiol surfaces on surface plasmon resonance biosensors for detection of Staphylococcus aureus. Sens. Act. B 2006, 114, 192-198.

108. Tims, T.B.; Lim, D.V. Rapid detection of Bacillus anthracis spores directly from powders from an evanescent wave fiber-optic biosensor. J. Microbiol. Methods 2004, 59, 127-130.

109. Campbell, G.A.; Mutharasan, R. Method of measuring Bacillus anthracis spores in the presence of copious amounts of Bacillus thuringiensis and Bacillus cereus. Anal. Chem. 2007, 79, $1145-$ 1152.

110. Song, J.M.; Culha, M.; Kasili, P.M.; Griffin, G.D.; Vo-Dinh, T. A compact CMOS biochip immunosensor towards the detection of a single bacteria. Biosens. Bioelectron. 2005, 20, 2203-2209. 
111. Uithoven, K.A.; Schmidt, J.C.; Ballman, M.E. Rapid identification of biological warfare agents using an instrument employing a light addressable potentiometric sensor and a flow-through immunofiltration-enzyme assay system. Biosens. Bioelectron. 2000, 14, 761-770.

112. Meyer, M.H.F.; Krause, H.J.; Hartmann, M.; Miethe, P.; Oster, J.; Keusgen, M. Francisella tularensis detection using magnetic labels and a magnetic biosensor based on frequency mixing. J. Magn. Mag. Mat. 2007, 311, 259-263.

113. He, F.; Zhang, L. Rapid diagnosis of M. tuberculosis using a piezoelectric immunosensor. Anal. Sci. 2002, 18, 397-401.

114. Díaz-González, M.; González-García, M.B.; Costa-García, A. Immunosensor for Mycobacterium tuberculosis on screen-printed carbon electrodes. Biosens. Bioelectron. 2005, 20, 2035-2043.

115. García-Ojeda, P.A.; Hardy, S.; Kozlowski, S.; Stein, K.E.; Feavers, I.M. Surface plasmon resonance analysis of antipolysaccharide antibody specificity: Responses to meningococcal group C conjugate vaccines and bacteria. Infect. Immun. 2004, 72, 3451-3460.

116. Rao, V.K.; Sharma, M.K.; Goel, A.K.; Singh, L.; Sekhar, K. Amperometric immunosensor for the detection of Vibrio cholerae O1 using disposable screen-printed electrodes. Anal. Sci. 2006, 22, 1207-1211.

117. Jyoung, J.Y.; Hong, S.; Lee, W.; Choi, J.W. Immunosensor for the detection of Vibrio cholerae O1 using surface plasmon resonance. Biosens. Bioelectron. 2006, 21, 2315-2319.

118. Meyer, M.H.F.; Stehr, M.; Bhuju, S.; Krause, H.J.; Hartmann, M.; Miethe, P.; Singh, M.; Keusgen, M. Magnetic biosensor for the detection of Yersinia pestis. J. Microbiol. Methods 2007, 68, 218-224.

119. Skottrup, P.D.; Nicolaisen, M.; Justesen, A.F. Towards on-site pathogen detection using antibodybased sensors. Biosens. Bioelectron. 2008, 24, 339-348.

120. Skottrup, P.; Nicolaisen, M.; Justesen, A.F. Rapid determination of Phytophthora infestans sporangia using a surface plasmon resonance immunosensor. J. Immunol. Methods 2007, 68, 507-515.

121. Skottrup, P.; Hearty, S.; Frøkiaer, H.; Leonard, P.; Hejgaard, J.; O’Kennedy, R.; Nicolaisen, M.; Justesen, A.F. Detection of fungal spores using generic surface plasmon resonance immunoassay. Biosens. Bioelecton. 2007, 22, 2724-2729.

122. Muramatsu, H.; Kajiwara, K.; Tamiya, E. and Karube, I. Piezoelectric immuno sensor for the detection of Candida albicans microbes. Anal. Chim. Acta 1986 188, 257-261.

123. Medyantseva, E.P.; Khaldeeva, E.V.; Glushko, N.I.; Budnikov, H.C. Amperometric enzyme immunosensor for the determination of the antigen of the pathogenic fungi Trichophyton rubrum. Anal. Chim. Acta 2000, 411, 13-18.

124. Keller, N.P.; Turner, G.; Bennett, J.W. Fungal secondary metabolism - from biochemistry to genomics. Nat. Rev. Microbiol. 2005, 3, 937-947.

125. Daly, S.J.; Keating, G.J.; Dillon, P.P.; Manning, B.M.; O’Kennedy, R.; Lee, H.A.; Morgan, M.R.A. Development of surface plasmon resonance-based immunoassay for aflatoxin $\mathrm{B}_{1} . J$. Agric. Food Chem. 2000, 48, 5097-5104.

126. Daly, S.J.; Dillon, P.P.; Manning, B.M.; Dunne, L.; Killard, A. and O'Kennedy, R. Production and characterisation of murine single chain $\mathrm{Fv}$ antibodies to aflatoxin B-1 derived from a preimmunised antibody phage display library system. Food Agric. Immunol. 2002, 14, 255-274. 
127. Dunne, L.; Daly, S.; Baxter, A.; Haughey, S.; O’Kennedy, R. Surface plasmon resonance-based immunoassay for the detection of aflatoxin B-1 using single-chain antibody fragments. Spectroscopy Lett. 2005, 38, 229-245.

128. Adányi, N.; Levkovets, I.A.; Rodriguez-Gil, S.; Ronald, A.; Váradi, M.; Szendro, I. Development of immunosensor based on OWLS technique for determining aflatoxin B1 and ochratoxin A. Biosens. Bioelectron. 2007, 22, 797-802.

129. Sournia, A.; Chrdtiennot-Dinet, M.J.; Ricard, M. Marine phytoplankton: How many species in the world ocean? J. Plankton Res. 1991, 13, 1093-1099.

130. Van Egmond, H.P.; Speijers, G.J.A.; Van den Top, H.J. Current situation on worldwide regulations for marine phycotoxins. J. Natural Toxins 1992, 1, 67-85.

131. Koenig, B.; Graetzel, M. A novel immunosensor for herpes viruses. Anal. Chem. 1994, 66, 341-344.

132. Rickert, J.; Göpel, W.; Beck, W.; Jung, G.; Heiduschka, P. A 'mixed' self-assembled monolayer for an impedimetric immunosensor. Biosens. Bioelectron. 1996, 11, 757-768.

133. Uttenthaler, E.; Kösslinger, R.; Drost, S. Characterisation of immobilization methods for African swine fever virus protein and antibodies with a piezoelectric immunosensor. Biosens. Bioelectron. 1998, 13, 1279-1286.

134. Ditcham, W.G.; Al-Obaidi, A.H.; McStay, D.; Mottram, T.T.; Brownlie, J.; Thompson, I. An immunosensor with potential for the detection of viral antigens in body fluids, based on surface second harmonic generation. Biosens. Bioelectron. 2001, 16, 221-224.

135. Eun, A.J.; Huang, L.; Chew, F.T.; Li, S.F.; Wong, S.M. Detection of two orchid viruses using quartz crystal microbalance (QCM) immunosensors. J. Virol. Methods 2002, 99, 71-79.

136. Zuo, B.; Li, S.; Guo, Z.; Zhang, J.; Chen, C. Piezoelectric immunosensor for SARS-associated coronavirus in sputum. Anal. Chem. 2004, 76, 3536-3540.

137. Minunni, M.; Tombelli, S.; Gullotto, A.; Luzi, E.; Mascini, M. Development of biosensors with aptamers as bio-recognition element: The case of HIV-1 Tat protein. Biosens. Bioelectron. 2004, 20, 1149-1156.

138. Konry, T.; Novoa, A.; Shemer-Avni, Y.; Hanuka, N.; Cosnier, S.; Lepellec, A.; Marks, R.S. Optical fiber immunosensor based on a poly(pyrrole-benzophenone) film for the detection of antibodies to viral antigen. Anal. Chem. 2005, 1771-1779.

139. Torrance, L.; Ziegler, A.; Pittman, H.; Paterson, M.; Toth, R.; Eggleston, I. Oriented immobilisation of engineered single-chain antibodies to develop biosensors for virus detection. $J$. Virol. Methods 2006, 134, 164-170.

140. Yu, J.S.; Liao, H.X.; Gerdon, A.E.; Huffman, B.; Scearce, R.M.; McAdams, M.; Alam, S.M.; Popernack, P.M.; Sullivan, N.J.; Wright, D.; Cliffel, D.E.; Nabel, G.J.; Haynes, B.F. Detection of Ebola virus envelope using monoclonal and polyclonal antibodies in ELISA, surface plasmon resonance and a quartz crystal microbalance immunosensor. J. Virol. Methods 2006, 137, 219228.

141. Huang, J.G.; Lee, C.L.; Lin, H.M.; Chuang, T.L.; Wang, W.S.; Juang, R.H.; Wang, C.H.; Lee, C.K.; Lin, S.M.; Lin, C.W. A miniaturized germanium-doped silicon dioxide-based surface plasmon resonance waveguide sensor for immunoassay detection. Biosens. Bioelectron. 2006, 22, 519-525. 
142. Sobarzo, A.; Paweska, J.T.; Herrmann, S.; Amir, T.; Marks, R.S.; Lobel, L. Optical fiber immunosensor for the detection of IgG antibody to Rift Valley fever virus in humans. J. Virol. Methods 2007, 146, 327-334.

143. Ionescu, R.E.; Cosnier, S.; Herrmann, S.; Marks, R.S. Amperometric immunosensor for the detection of anti-West Nile virus IgG. Anal. Chem. 2007, 79, 8662-8668.

144. Lehane, L. Paralytic shellfish poisoning: A review. National Office of Animal and Plant Health, Agriculture, Fisheries and Forestry: Australia, 2000.

145. Pan, Y.; Parsons, M.L.; Busman, M.; Moeller, P.D.R.; Dortch, Q.; Powell, C.L.; Douchette, G.J. Pseudo-nitzschia spp. of Pseudodelicatissima - a confirmed producer of domoic acid from the northern gulf of Mexico. Marine Ecol. Prog. Ser. 2001, 220, 83-92.

146. Bowden, B.F. Yessotoxins-polycyclic ethers from dinoflagellates: Relationships to diarrhetic shellfish toxins. Toxin Rev. 2006, 25, 137-157.

147. Satake, M.; MacKenzie, L.; Yasumoto, T. Identification of Protoceratium reticulatum as a biogenetic origin of yessotoxin. Nat. Toxins 1997, 5, 164-167.

148. Falconer, I.R.; Humpage, A.R. Health risk assessment of cyanobacterial (blue-green algal) toxins in drinking water. Int. J. Environ. Public Health 2005, 2, 43-50.

149. Hirama, M. Total synthesis of ciguatoxin CTX3C: A venture into the problems of ciguatera seafood poisoning. The Chem. Rec. 2005, 5, 240-250.

150. Carter, R.M.; Poli, M.A.; Pesavento, M.; Sibley, D.E.T.; Lubrano, G.J.; Guilbault, G.G. Immunoelectrochemical biosensors for detection of saxitoxin and brevetoxin. Immunomethods 1993, 3, 128-133.

151. Kreuzer, M.P.; Pravda, M.; O’Sullivan, C.K.; Guilbault, G.G. Novel electrochemical immunosensors for seafood toxin analysis. Toxicon 2002, 40, 1267-1274.

152. Kania, M.; Kreuzer, M.; Moore, E.; Pravda, M.; Hock, B.; Guilbault, G. Development of polyclonal antibodies against domoic acid for their use in electrochemical biosensors. Anal. Lett. 2003, 36, 1851-1863.

153. Lotierzo, M.; Henry, O.Y.; Piletsky, S.; Tothill, I.; Cullen, D.; Kania, M.; Hock, B.; Turner, A.P. Surface plasmon resonance sensor for domoic acid based on grafted imprinted polymer. Biosens. Bioelectron. 2004, 20, 145-152.

154. Yu, Q.; Chen, S.; Taylor, A.D.; Homola, J.; Hock, B.; Jiang, S. Detection of low-molecularweight domoic acid using surface plasmon resonance sensor. Sens. Act. B 2005, 107, 193-201.

155. Stevens, R.C.; Soelberg, S.D.; Eberhart, B.T.L.; Spencer, S.; Wekell, J.C.; Chinowsky, T.M.; Trainer, V.L.; Furlong, C.E. Detection of the toxin domoic acid from clam extracts using a portable surface plasmon resonance biosensor. Harm. Algae 2007, 6, 166-174.

156. Long, F.; He, M.; Shi. H.C.; Zhu, A.N. Development of evanescent wave all-fiber immunosensor for environmental water analysis. Biosens. Bioelectron. 2008, 23, 952-958.

157. Loyprasert, S.; Thavarungkul, P.; Asawatreratanakul, P.; Wongkittisuksa, B.; Limsakul, C.; Kanatharana, P. Label-free capacitive immunosensor for microcystin-LR using self-assembled thiourea monolayer incorporated with $\mathrm{Ag}$ nanoparticles on gold electrode. Biosens. Bioelectron. 2008, 24, 78-86.

158. Long, F.; He, M.; Zhu, A.N.; Shi, H.C. Portable optical immunosensor for highly sensitive detection of microcystin-LR in water samples. Biosens. Bioelectron. 2009, 24, 2346-2351. 
159. Marquette, C.A.; Coulet, P.R.; Blum, L.J. Semi-automated membrane based on chemiluminescent immunosensor for flow injection analysis of okadaic acid in mussels. Anal. Chim. Acta 1999, 398, 173-182.

160. Tang, A.X.J.; Pravda, M.; Guilbault, G.G.; Piletsky, S.; Turner, A.P.F. Immunosensor for okadaic acid using quartz crystal microbalance. Anal. Chim. Acta 2002, 471, 33-40.

161. Tang, A.; Kreuzer, M.; Lehane, M.; Pravda, M.; Guilbault, G.G. Immunosensor for the determination of okadaic acid based on screen-printed electrode. Int. J. Environ. Anal. Chem. 2003, 83, 663-670.

162. Campás, M.; de la Igleisa, P.; Le Berre, M.; Kane, M.; Diogéne, J.; Marty, J.L. Enzymatic recycling-based amperometric immunosensor for the ultrasensitive detection of okadaic acid in shellfish. Biosens. Bioelectron. 2008, 24, 716-722.

163. Satake, M.; Ofuki, K.; Naoki, H.; James, K.J.; Furey, A.; McMahon, T.; Silke, J.; Yasumoto, T. Azaspiracid, a new marine toxin having unique spiro ring assemblies, isolated from Irish mussels, Mytilus edulis. J. Am. Chem. Soc. 1998, 120, 9967-9968.

164. Twiner, M.J.; Rehmann, N.; Hess, P.; Douchette, G.J. Azaspiracid shellfish poisoning: A review on the chemistry, ecology, and toxicology with an emphasis on human health impacts. Mar. Drugs 2008, 6, 39-72.

165. Hess, P.; Nguyen, L.; Aasen, J.; Keogh, M.; Kilcoyne, J.; McCarron, P.; Aune, T. Tissue distribution, effects of cooking and parameters affecting the extraction of azaspiracids from mussels, Mytilus edulis, prior to analysis by liquid chromatography coupled with mass spectrometry. Toxicon 2005, 46, 62-71.

166. Forsyth, C.J.; Xu, J.; Nguyen, S.T.; Samdal, I.A.; Briggs, L.R.; Rundberget, T.; Sandvik, M.; Miles, C.O. Antibodies with broad specificity to azaspiracids by use of synthetic haptens. J. Am. Chem. Soc. 2006, 128, 15114-15116.

167. Campbell, G.A.; Mutharasan, R. Near real-time detection of Cryptosporidium parvum oocyst by IgM-functionalized piezoelectric-excited millimeter-sized cantilever biosensor. Biosens. Bioelectron. 2008, 23, 1039-1045.

168. Kang, C.D.; Cao, C.; Lee, J.; Choi, I.S.; Kim, B.W.; Sim, S.J. Surface plasmon resonance-based inhibition assay for real-time detection of Cryptosporidium parvum oocyst. Water Res. 2008, 42, 1693-1699.

169. Zhou, Y.M.; Liu, G.D.; Wu, Z.Y.; Shen, G.L.; Yu, R.Q. An amperometric immunosensor based on a conducting immunocomposite electrode for the determination of Schistosoma japonicum antigen. Anal. Sci. 2002, 18, 155-159.

170. Zhou, Y.M.; Wu, Z.Y.; Shen, G.L.; Yu, R.Q. An amperometric immunosensor based on nafionmodified electrode for the detection of Schistosoma japonicum antibody. Sens. Act. B 2003, 89, 292-298.

171. Zhong, T.S.; Liu, G. Silica sol-gel amperometric immunosensor for Schistosoma japonicum antibody assay. Anal. Sci. 2004, 20, 537-541.

172. Wu, Z.; Wu, J.; Wang, S.; Shen, G.; Yu, R. An amplified mass piezoelectric immunosensor for Schistosoma japonicum. Biosens. Bioelectron. 2006, 22, 207-212. 
173. Nagel, T.; Gajovic-Eichelmann, N.; Tobisch, S.; Schulte-Spechtel, U.; Bier, F.F. Serodiagnosis of Lyme borreliosis infection using surface plasmon resonance. Clin. Chim. Acta 2008, 394, 110113.

174. Hahm, B.K.; Bhunia, A.K. Effect of environmental stresses on antibody-based detection of Escherichia coli O157:H7, Salmonella enterica serotype Enteritidis and Listeria monocytogenes. J. Appl. Microbiol. 2006, 100, 1017-1027.

175. Needham, R.; Williams, J.; Beales, N.; Voysey P.L.; Magan, N. Early detection and differentiation of spoilage of bakery products. Sens. Act. B 2005, 106, 20-23.

176. Alocilja, E.C.; Ritchie, N. L.; Grooms, D. L. Protocol development using an electronic nose for differentiating E. coli strains. IEEE Sens. J. 2003, 3, 801-805.

177. Balasubramanian, S.; Panigrahi, S.; Logue, C. M.; Marchello, M.; Sherwood, J.S. Identification of Salmonella-inoculated beef using a portable electronic nose system. J. Rapid Methods Auto. Microbiol. 2005, 13, 71-95.

178. Scampicchio, M.; Ballabio, D.; Arecchi, A.; Cosio, S.M.; Mannino, S. Amperometric electronic tongue for food analysis. Microchim. Acta. 2008, 163, 11-21.

179. Lan, Y.B.; Wang, S.Z.; Yin, Y.G., Hoffmann, C.W.; Zheng, X.Z. Using a surface plasmon resonance biosensor for rapid detection of Salmonella typhimurium in chicken carcass. J. Bionic Eng. 2008, 5, 239-246.

180. Ngundi, M.M.; Kulagina, N.V.; Anderson, G.P.; Taitt, C.R. Nonantibody-based recognition: Alternative molecules for detection of pathogens. Exp. Rev. Proteomics 2006, 3, 511-524.

181. Mascini, M.; Macagnano, A.; Monti, D.; Del Carlo, M.; Paolesse, R.; Chen, B.; Warner, P.; D’Amico, A.; Di Natale, C.; Compagnone, D. Piezoelectric sensors for dioxins: A biomimetic approach. Biosens. Bioelectron. 2004, 20, 1203-1210.

182. Kulagina, N.V.; Shaffer, K.M.; Anderson, G.P.; Ligler, F.S.; Taitt, C.R. Antimicrobial peptidebased array for Escherichia coli and Salmonella screening. Anal. Chim. Acta 2006, 575, 9-15.

183. Pan, Q.; Zhang X.L.; Wu, H.Y. Aptamers that preferentially bind type IVB pili and inhibit human monocytic-cell invasion by Salmonella enterica serovar typhi. Antimicrob. Agents Chemother. 2006, 49, 4052-4060.

184. Mazarei, M.; Teplova, I.; Hajimorad, M.R.; Stewart, Jr., C.N. Pathogen phytosensing: Plants to report plant pathogens. Sensors 2008, 8, 2628-2641.

(C) 2009 by the authors; licensee Molecular Diversity Preservation International, Basel, Switzerland. This article is an open-access article distributed under the terms and conditions of the Creative Commons Attribution license (http://creativecommons.org/licenses/by/3.0/). 